Prepared in cooperation with the United States Army Corps of Engineers

\title{
Sediment Samples and Channel-Geometry Data, Lower Platte River Watershed, Nebraska, 2010
}

Data Series 572

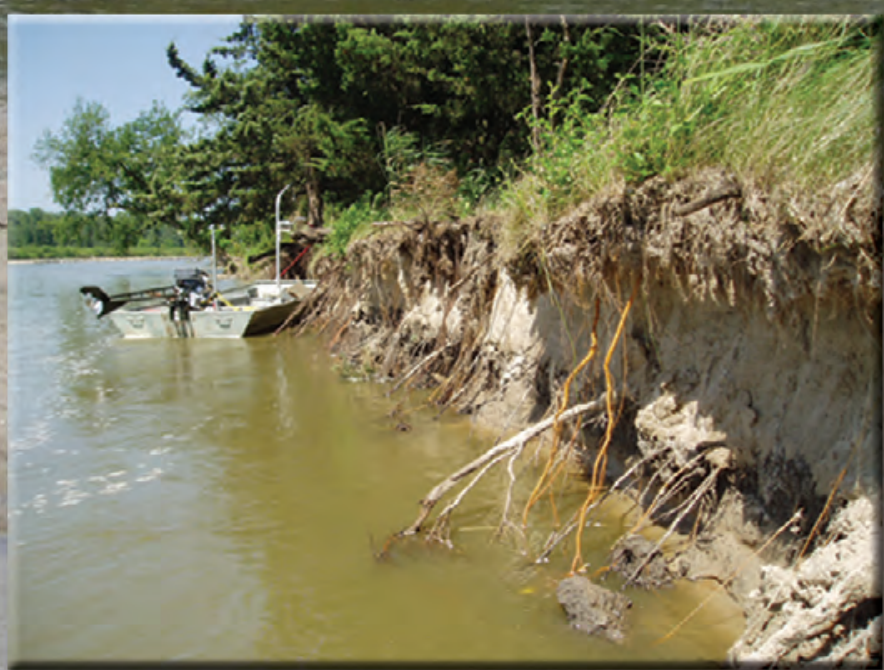


Cover. The Platte River in Nebraska (background photograph).

Upper right photograph: Typical bank of Platte River after bank was prepared for sampling.

Middle right photograph: Platte River sandbar with US BMH-53 sampler in foreground and rotating laser level and boat in background.

Lower right photograph: Platte River bank, typical of the type of banks selected for bank sampling.

Photographs by Nathaniel Schaepe, U.S. Geological Survey. 


\section{Sediment Samples and Channel-Geometry Data, Lower Platte River Watershed, Nebraska, 2010}

By Nathaniel J. Schaepe and Jason S. Alexander

Prepared in cooperation with the United States Army Corps of Engineers

Data Series 572 


\section{U.S. Department of the Interior \\ KEN SALAZAR, Secretary \\ U.S. Geological Survey \\ Marcia K. McNutt, Director}

\section{U.S. Geological Survey, Reston, Virginia: 2011}

For more information on the USGS - the Federal source for science about the Earth, its natural and living resources, natural hazards, and the environment, visit http://www.usgs.gov or call 1-888-ASK-USGS

For an overview of USGS information products, including maps, imagery, and publications, visit http://www.usgs.gov/pubprod

Any use of trade, product, or firm names is for descriptive purposes only and does not imply endorsement by the U.S. Government.

Although this report is in the public domain, permission must be secured from the individual copyright owners to reproduce any copyrighted materials contained within this report.

Suggested citation:

Schaepe, N.J., and Alexander, J.S., 2011, Sediment samples and channel-geometry data, lower Platte River watershed, Nebraska, 2010: U.S. Geological Survey Data Series 572, 22 p. 


\section{Contents}

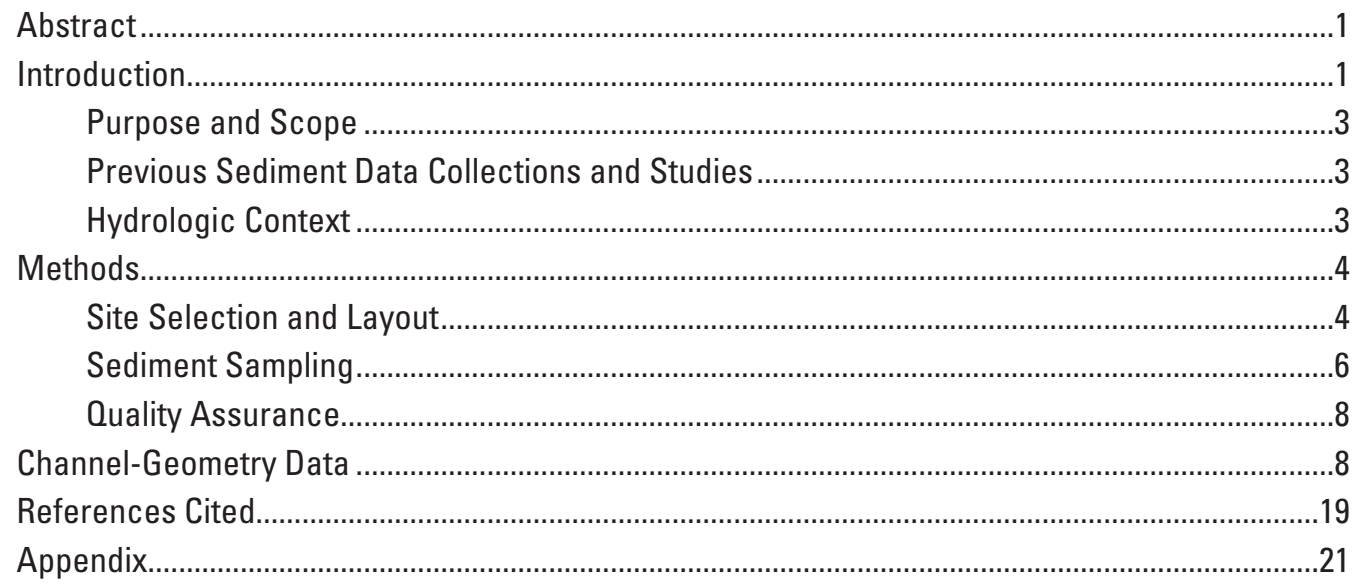

\section{Figures}

1. Map showing location of study area, stream gages, sample-collection sites, and river reaches.

2. Graph showing daily mean streamflow for Platte River near Ashland, Nebraska, for water year 2010, and selected daily percentiles of mean streamflow for 21 years of record (1989-2009).

3. Platte River hydrographs showing short-term hydrologic conditions at sediment-sample collection times by pairing each sample location with nearest streamflow-gaging station

4. Graphs showing grain-size information for six sandbar-sediment samples collected with two different samplers at a single location on the lower Platte River, Nebraska, 2010

\section{Tables}

1. Lower Platte River sediment-sampling plan

2. Summary of sediment-sampling sites in lower Platte River watershed, Nebraska, 2010.

3. Sample locations and data associated with bank-sediment samples, lower Platte River watershed, Nebraska, 2010

4. Sample locations and data associated with sandbar-sediment samples, lower Platte River, Nebraska, 2010

5. Sample locations and channel-geometry data associated with bed-sediment subsamples, lower Platte River watershed, Nebraska, 2010 


\section{Conversion Factors}

\begin{tabular}{lcl}
\hline Multiply & By & To obtain \\
\hline inch (in.) & Length & \\
inch (in.) & 2.54 & centimeter $(\mathrm{cm})$ \\
foot (ft) & 25.4 & millimeter $(\mathrm{mm})$ \\
mile (mi) & 0.3048 & meter $(\mathrm{m})$ \\
\hline & 1.609 & kilometer $(\mathrm{km})$ \\
\hline foot per second $(\mathrm{ft} / \mathrm{s})$ & Flow rate & \\
cubic foot per second $\left(\mathrm{ft}^{3} / \mathrm{s}\right)$ & 0.3048 & meter per second $(\mathrm{m} / \mathrm{s})$ \\
\hline
\end{tabular}

Horizontal coordinate information is referenced to the North American Datum of 1983 (NAD 83). 


\title{
Sediment Samples and Channel-Geometry Data, Lower Platte River Watershed, Nebraska, 2010
}

\author{
By Nathaniel J. Schaepe and Jason S. Alexander
}

\section{Abstract}

The relation between channel width and stream physical habitat in the lower Platte River in eastern Nebraska was studied as part of the lower Platte River Cumulative Impact Study. The purpose of this component was to document the grain-size distribution of sediment deposited as specific types of physical features, such as sandbars, banks, and stream beds within different hydraulic habitats, within the lower Platte River system. In so doing, the major sources of sediment for sandbar creation downstream are described. Sediment samples were collected from 11 reaches of the lower Platte River from Silver Creek, Nebraska, to the mouth of the Platte River, and from 4 tributary streams. Two bed-material samples, 2 bank-material samples, and 3 sandbar-material samples were collected at main-stem sampling sites, and 1 sample each of bed material and bank material was collected at each tributary sampling site. Aspects of channel geometry, such as channel width, sandbar height and width, and bank height, were measured at each sampled site. This report presents the channel-geometry results and documents the sample-collection methods.

\section{Introduction}

The Platte River in Nebraska is a wide, shallow stream with a bed predominantly of sand, often characterized by multiple channel threads separated by wooded islands or sandbars. This type of channel morphology is ideal for nesting, foraging, and roosting habitat for certain migratory bird species because it provides a local aquatic food source along with protection from terrestrial predators. Two bird species known to use the Platte River, the interior least tern and whooping crane, are federally listed as endangered, and another species, the piping plover, is listed as threatened. Prior to development of upstream diversions and storage reservoirs, the typical morphology of the Platte River throughout Nebraska was a wide, shallow, sparsely wooded channel, with numerous barren mid-channel sandbars and wooded islands (Williams, 1978; Johnson and Boettcher, 2000). Reductions in flow and sediment transport of the Platte River since 1860 have resulted in changes to channel morphology (Eschner and others, 1983). The generalized pattern of channel morphologic changes can be described as narrowing, deepening, and coarsening (Eschner and others, 1983; Lyons and Randle, 1988; Johnson, 1994; Holburn and others, 2006; Joeckel and Henebry, 2008). Channel narrowing (reduction in overall channel width) has resulted from the establishment of riparian vegetation on sandbars, and likely has had the greatest overall negative impact on bird habitat, because nesting habitats for terns and plovers mainly are found on vegetated sandbars (Brown and Jorgensen, 2008). The magnitude of channel morphologic changes has been greatest upstream of Columbus, Nebraska (fig. 1), because two large downstream tributaries, the Loup River and Elkhorn River, have fewer dams and diversions than reaches upstream, and still contribute substantial volumes of water and sediment to the main stem (Joeckel and Henebry, 2008). Throughout this report, the Platte River upstream of the Loup River confluence is referred to as the central Platte River (CPR), and the Platte River downstream from the Loup River confluence is referred to as the lower Platte River (LPR) (fig. 1).

In cooperation with the U.S. Army Corps of Engineers (USACE), Omaha District, the U.S. Geological Survey (USGS) sampled river sediment and recorded channelgeometry data in the LPR as a component of a larger Cumulative Impact Study (CIS). The CIS was undertaken in response to concerns expressed by fish and wildlife managers that bank stabilization measures and levee projects could have an adverse effect on the endangered species that depend on the LPR for habitat (U.S. Army Corps of Engineers, 2008). Several Federal and State agencies have partnered in the CIS to study the cumulative effects of changes in bank protection, channelization, and flood-control practices on habitat in the LPR. Previous phases of the CIS investigated changes in land use (U.S. Army Corps of Engineers, 2008) and hydrology (Ginting and others, 2008) along the LPR over several series of time increments. Bank stabilization has the potential to decrease the amount of fine-grained sediments entering the active river channel. Additional bank stabilization is a main concern because sediment from banks alone can account for as much as 30 to 80 percent of a watershed's sediment yield 


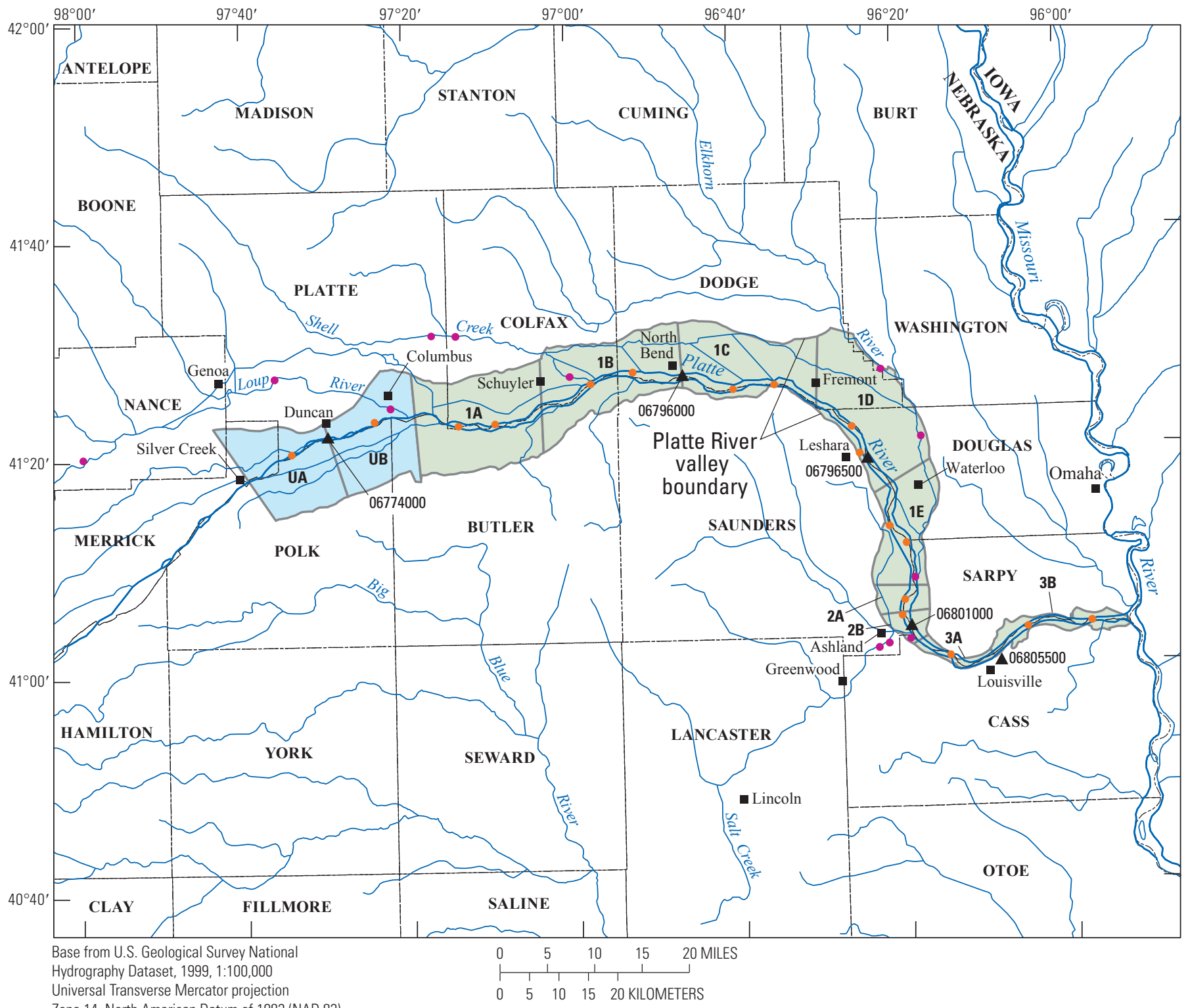

Zone 14, North American Datum of 1983 (NAD 83)

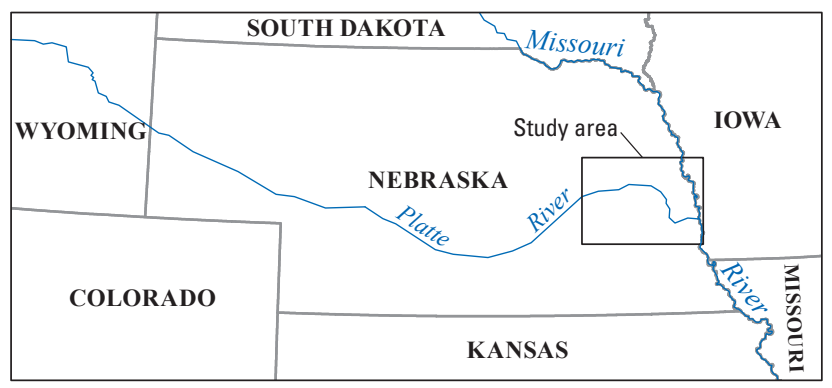

EXPLANATION

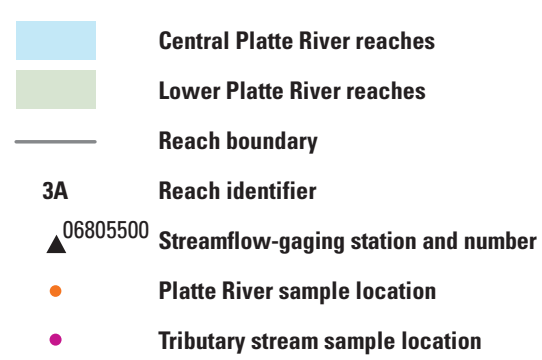

Figure 1. Map showing location of study area, stream gages, sample-collection sites, and river reaches 
(Bull and Kirkby, 1997; Simon and Darby, 1999; Sekely and others, 2002; Evans and others, 2006). Additionally, the effects of more constricted, deeper flow during floods (because of levees) on sandbar formation and geometry are unknown.

\section{Purpose and Scope}

The purpose of this report is to describe the study locations, methods, quality control, and channel-geometry data associated with a sediment-sampling effort in the LPR and its major tributaries. The sampling effort was performed as part of the third phase of the LPR CIS, and was completed in July and August of 2010. For the purposes of the larger CIS study, the major tributaries supplying sediment and water to the LPR are the CPR, Loup River, Shell Creek, Elkhorn River, and Salt Creek (fig. 1). Except for quality-control results, the data for grain-size distributions from the sediment-sampling effort described in this report are contributing to other study components to be reported by partner agencies and, therefore, are not presented in this report.

\section{Previous Sediment Data Collections and Studies}

Several previous studies have sampled bed and bank materials in various reaches of the Platte River in Nebraska (U.S. Army Corps of Engineers, 1935; Smith, 1971; Kircher, 1981; Kinzel and others, 1999; Holburn and others, 2006; HDR and others, unpub. data, 2009; Ayres Associates and Olsson Associates, 2009). These previous sampling efforts had varying spatial resolution, sampling techniques, and have occurred under varying hydrologic contexts (Kinzel and Runge, 2010), with most of the sampling focused in reaches of the CPR. The results of these previous studies indicate that in 1931 the median bed-sediment grain sizes in the LPR were similar to CPR reaches upstream. Since that time, grain sizes in reaches upstream from the Loup River have coarsened and become more variable (Kinzel and Runge, 2010). An investigation of the reasons for this pattern in grain-size variation that accounts for differences between sampling techniques, as well as the hydrologic and geomorphologic contexts of each sampling effort, has not been completed. None of the previous studies in the LPR incorporated a sampling strategy designed to investigate the variation in grain sizes between sandbar material, bed material, and bank material, nor how grain size in the main stem varies in relation to grain sizes in the bed and banks of major tributaries. An extensive study of grain-size characteristics in the LPR could provide valuable information about the sources of sediment in the LPR and the grain sizes necessary to create sandbar habitats useful for endangered bird species.

\section{Hydrologic Context}

Sediment grain sizes composing a river bed and sandbars are a result of several factors, including the volume and grain-size distribution of sediment sources and the nature of the localized hydraulic-flow field (Bridge, 2003). The primary sources of sediment contributing to a trunk stream are the tributary streams, the banks of the channel, floodplain gullying, and direct hillslope contributions (Reid and Dunne, 1996). Consequently, grain-size distributions of the bed and sandbars at any particular sampling moment are a combined reflection of the most recent or instantaneous flow conditions in the river channel, as well as recent hydrologic system history affecting the supplied volume and sizes of sediment from the primary sources.

Streamflow in the LPR and associated tributaries was substantially above normal during June and July 2010 (fig. 2). Heavy spring rains and late snowmelt in the Rocky Mountains combined to produce high flows basinwide. Of 34 streamflowgaging stations with at least 25 years of record in the Platte River watershed within Nebraska, 11 had instantaneous peak stages in 2010 that were among the 3 highest stages ever recorded (J.M. Lambrecht, USGS Nebraska Water Science Center, written commun., 2010). Streamflow of the Platte River near Ashland (USGS station-identification number 06801000 , fig. 1), was above the 80th percentile of its longterm daily mean streamflow rate from June 9 to July 4 (fig. 2). The provisional 2010 instantaneous peak flow near Ashland of 99,900 cubic feet per second $\left(\mathrm{ft}^{3} / \mathrm{s}\right)$, was just less than the 4-percent probability flow (25-year recurrence interval) computed by Soenksen and others (1999). Valid temporal comparisons of the data collected for the lower Platte River CIS with those from other studies will take into account differences in hydrologic context between study periods.

The LPR daily-streamflow regime is substantially affected by hydroelectric operations on the Loup River. Power generation cycles associated with the Loup River Hydroelectric Facility near Columbus, Nebraska, cause a diurnal fluctuation in streamflow between the hydroelectric tailrace, approximately 1.8 miles (mi) downstream from the Platte River confluence with the Loup River, and the Missouri River. In the tailrace, maximum streamflow is $4,800 \mathrm{ft}^{3} / \mathrm{s}$, causing a maximum variation in Platte River instantaneous discharge of the same magnitude at the confluence of the hydroelectric tailrace and the LPR. The amplitude of this fluctuation in streamflow attenuates in the downstream direction and results in daily-stage fluctuations of approximately 1.7 feet (ft) at the streamflow-gaging station at North Bend (station number 06796000) and approximately $0.4 \mathrm{ft}$ at the streamflow-gaging station near Louisville (station number 06805500). During the time period of sample collection, daily streamflow minima and 


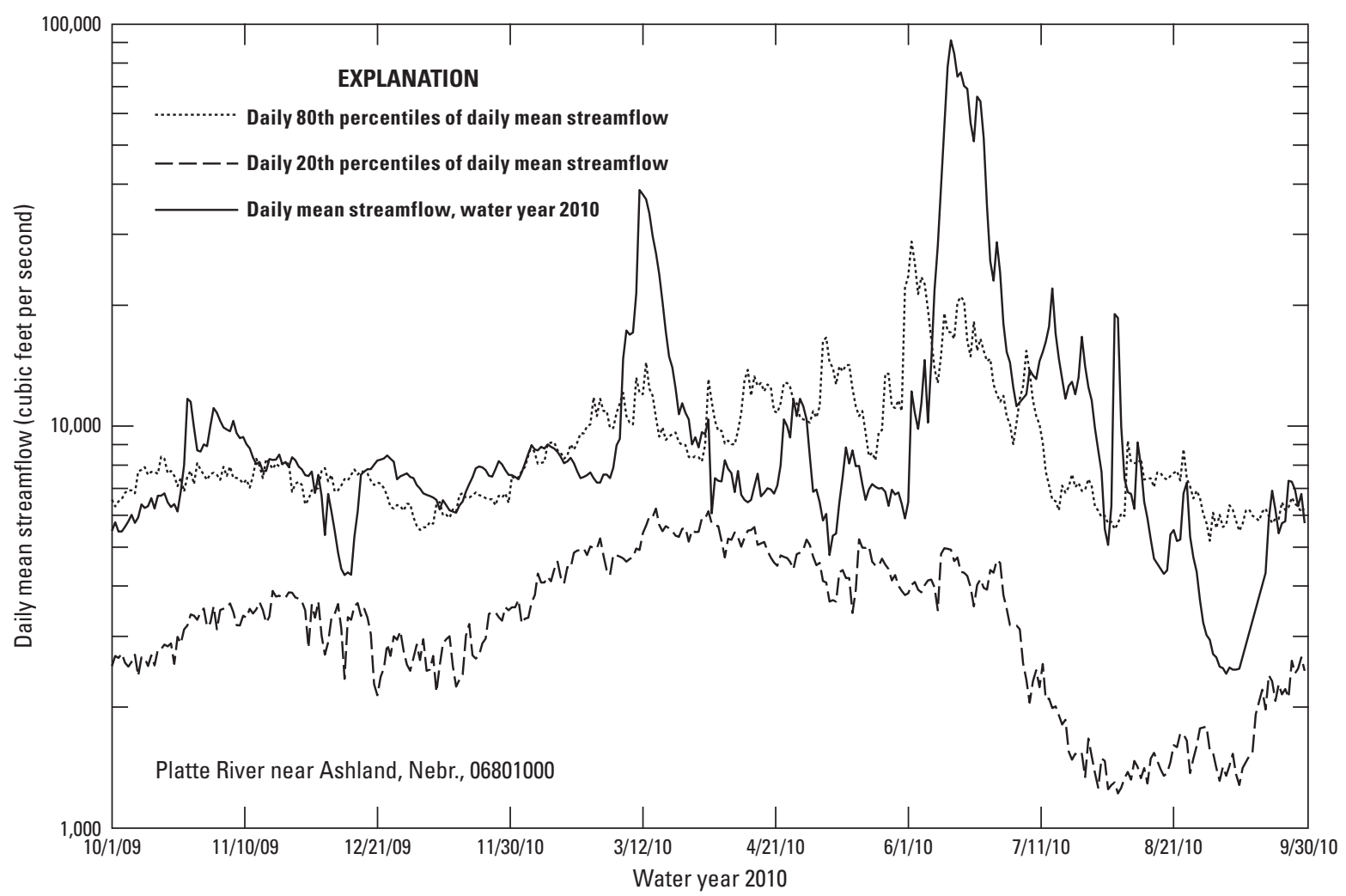

Figure 2. Graph showing daily mean streamflow for Platte River near Ashland, Nebraska, for water year 2010, and selected daily percentiles of mean streamflow for 21 years of record (1989-2009).

maxima differed by between 3,000 and $6,000 \mathrm{ft}^{3} / \mathrm{s}$, depending on the day and site (fig. 3). Because of this diurnal stage change, some of the sandbars that were sampled might have been submerged during the peak stage of the day, and some of the shallow bed-material samples might have been exposed at the low stage of the day.

\section{Methods}

The approach used for the effort described in this report was to determine the variation in sediment grain sizes by sampling various sources and sinks of sediment as well as measuring variation among contrasting hydraulic environments. In the case of the LPR, the considered sources of sediment were major tributaries upstream, the CPR, and the LPR channel. Bank material is a source, and was considered also to be a sink for indefinite storage, of sediment. The bed and sandbars were considered temporary sinks of sediment, becoming sources during high-magnitude flow events when the channel scours. The complex mixture of shallow- and deep-water environments also indicated that an additional stratification based on hydraulics potentially would document co-variation of the grain-size distribution of the bed material with depth and velocity combinations. Channel-geometry data were collected to document the correlations of grain size and sandbar width with channel width.

\section{Site Selection and Layout}

Seventeen samples distributed among 11 reaches were collected along the Platte River from Silver Creek, Nebr., to the mouth, and 12 samples were collected along 4 major 

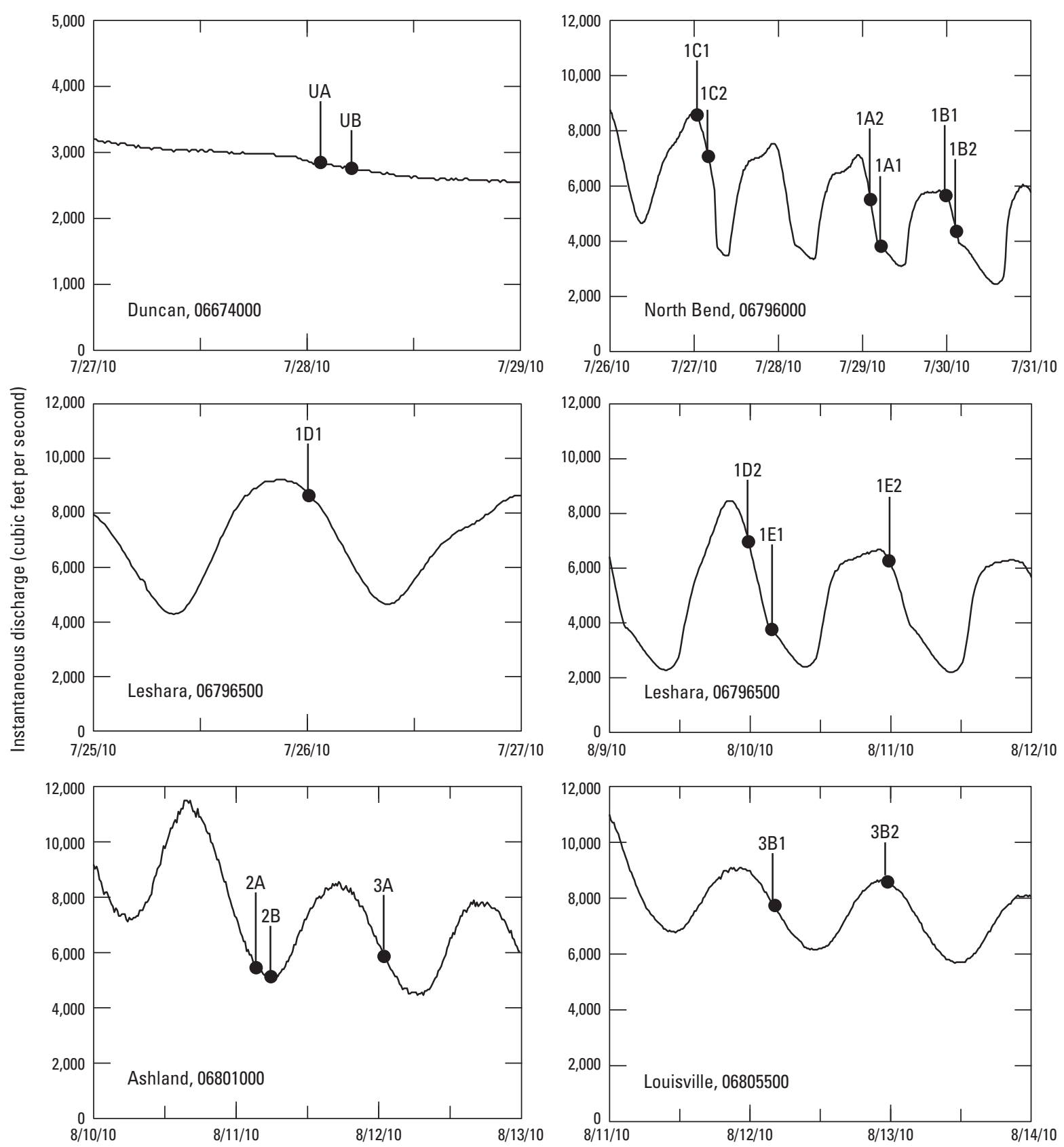

EXPLANATION

Streamflow at time of sample collection at streamflow-gaging station indicated by station number (fig. 1)

3A Reach identifier or reach-sample site number (fig. 1)

Figure 3. Platte River hydrographs showing short-term hydrologic conditions at sediment-sample collection times by pairing each sample location with nearest streamflow-gaging station 
Sediment Samples and Channel-Geometry Data, Lower Platte River Watershed, Nebraska, 2010

tributaries to the LPR (fig. 1). The number of each type of collected sample and the sampling strategy varied between main-stem and tributary locations. At each main-stem sample location, two composited bed-material samples, two bankmaterial samples, and three sandbar-material samples were collected. At each sample location along major tributaries, one bed-material sample and one bank-material sample were collected. At main-stem locations, composited bed-material samples were intended to broadly represent two hydraulic microhabitats of the Platte River channel, one a deeperswifter microhabitat representing channel thalwegs (deepswift habitat type), and the other a shallow microhabitat with more slowly flowing current (shallow-slow), representing the habitat type commonly located at the submerged periphery of channel sandbars. The hydraulic characteristics used to define the physical distinction in the field were the combination of water $2 \mathrm{ft}$ deep and a current velocity of 2 feet per second (fps), based, in part, on the hydraulic microhabitat criteria presented in Ginting and Zelt (2008) for the LPR. Three sediment samples were collected in channel hydraulic environments deeper and swifter than this boundary and composited to represent the deep-swift microhabitat type. Another three samples were collected in hydraulic environments shallower and slower than this boundary, and composited to represent the shallow-slow microhabitat type.

Systematic spacing between sampling sites was intended to maintain even spacing between sampling sites within the boundaries of the river reaches designated by the USACE (table 1). In shorter reaches (less than $10 \mathrm{mi}$ ) of the main stem, only one sample location was designated, and the target location was the midpoint of the reach (fig. 1). In longer reaches (greater than $10 \mathrm{mi}$ ), two sampling locations were designated, and the target sampling locations were points at one- and twothirds distance from the upstream or downstream boundary. In tributaries, one sample was designated for collection within the broader Platte River valley, near the confluence, and two were designated for collection upstream of the valley boundary (fig. 1). Since a substantial portion of the Elkhorn River resides within the Platte River valley, all three samples were collected within the Platte River valley, but one was collected near the Platte River confluence and two were collected a minimum of $5 \mathrm{mi}$ upstream from the confluence. Actual sampling locations were chosen based on a combination of the 2007 National Agriculture Imagery Program aerial photographs (Farm Service Agency, 2007) and field-based assessments of geomorphic features. An ideal sampling situation would have been a river cross section exactly at the targeted sampling location that included three emergent sandbars, three deep-swift threads, numerous shallow-slow habitat environments, and exposed (recently eroded) vertical channel banks on at least one side of the river. In almost every case, such sampling situations did not exist at the targeted sampling locations. Instead, after navigating by global positioning system (GPS) receiver to the coordinates of the targeted sampling location, a buffer of 1 mi upstream and downstream from the target was examined to locate a segment of river that had the array of adequate sampling conditions.

\section{Sediment Sampling}

Once the sampling location was identified, all samples were collected within a cross-sectional band having an arbitrary maximum length (streamwise) of 4,500 ft. Geographic coordinates of all sample points were recorded with a handheld GPS receiver while the Wide-Area Augmentation System, an accuracy-improvement feature, was enabled.

Bed-material samples were collected in each of two different hydraulic microhabitat types at each sampling location. Deep-swift threads of flow were located visually and water depths and current velocities were investigated and confirmed using a graduated wading rod and an acoustic Doppler velocimeter (ADV). Samples at locations that had multiple channel threads were a composite of subsamples from three separate channels that shared the same hydraulic microhabitat type. Bed-material samples were collected with a US BMH-60 sampler (Edwards and Glysson, 1999; Davis, 2005). This sampler is cast aluminum, and its fins help maintain its orientation to the current. A half-cylinder trap on the bottom of the sampler is used to collect the sample. With the half-cylinder trap locked in an open position, the sampler was lowered to the streambed while suspended on a handline or cable. Once the sampler contacts the bed, line tension is released, allowing the trap to rotate and enclose the bed-material sample. Deep-swift microhabitats were sampled with the aid of a winch mounted on a boat. Shallow-slow habitats were sampled while wading. The distance of each channel sample point from the nearest bank was measured with a laser range finder. Water depth and current velocity were measured at each sampling point using a graduated wading rod and ADV.

Three sandbar-material samples were collected within each sampling location. Sandbar samples were collected with a US BMH-53 bed-material sampler (Edwards and Glysson, 1999; Davis, 2005). This sampler features an 8-inch long cylinder that contains a tight-fitting brass piston. The sampler is driven into the soil or sediment deposit as the piston moves upward, allowing sample material to enter the container. After removing the sampler from the deposit, the piston is pushed back down, forcing the sample out into a container. To ensure that the thicknesses of each sampled volume were approximately the same for bed-material samples and sandbar-material samples, a stop indicator was placed on the US BMH-53 so that the cylinder sampling depth was approximately the same as the radius of the half-cylinder trap on the US BMH-60. If three or more emergent sandbars were present, the highest sandbar and two other sandbars were sampled, collecting from the highest point of each of the three sandbars. When only two sandbars were present, the largest sandbar was sampled in two different locations based on the formation of the sandbar. A sample was taken at a high point of the sandbar and then at either a lower point of the sandbar 
Table 1. Lower Platte River sediment-sampling plan.

[Reach identifiers correspond to figure 1; river miles are referenced to the river mouth; NA, not applicable; Hwy, highway]

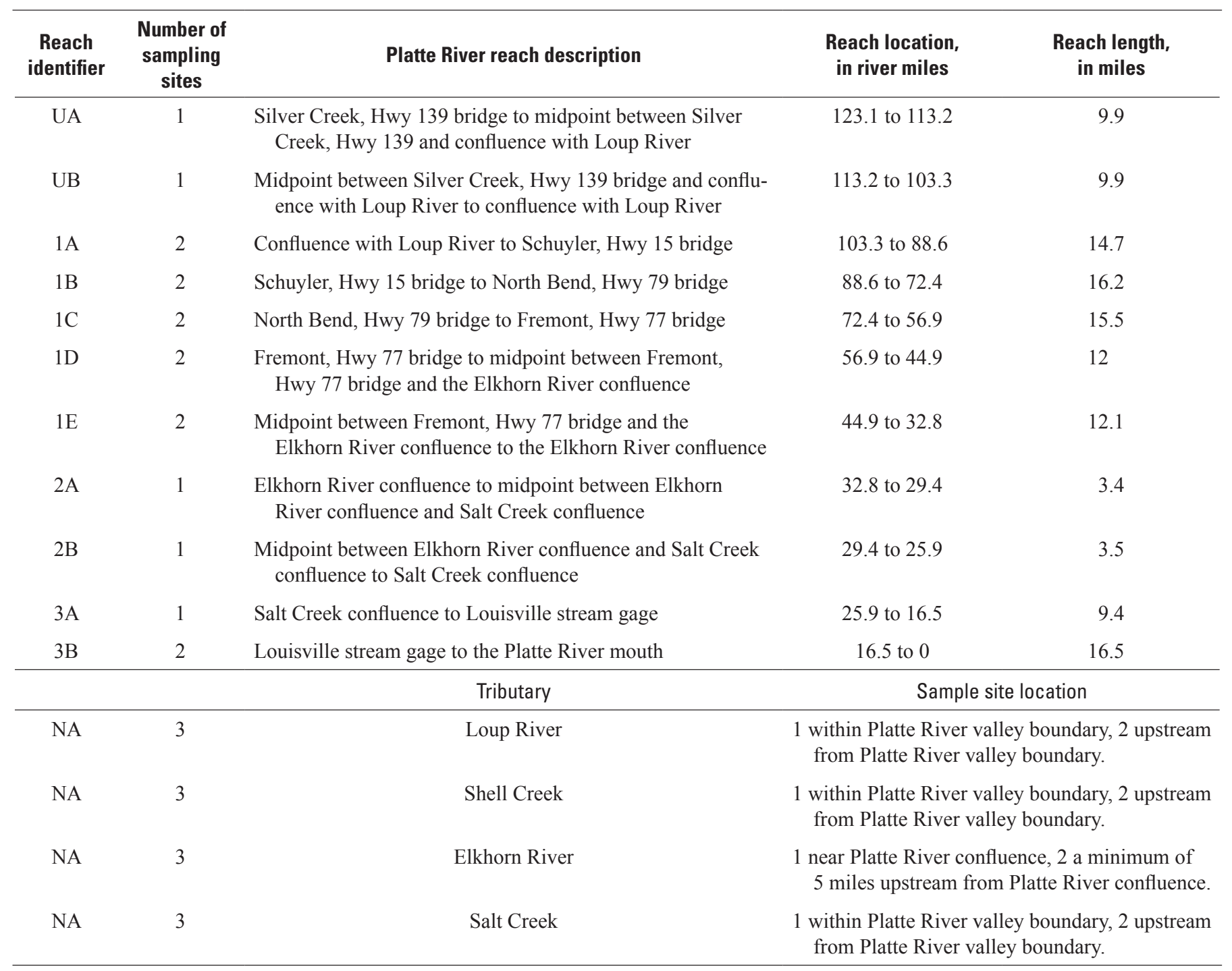


or at a point of the sandbar that appeared to have been deposited more recently than the other areas of the sandbar. In cases where only one emergent sandbar was present, the sandbar was sampled at three different locations, selected to represent variations in the sandbar elevations. The height of the sandbar relative to the water surface was measured at each sample point using a rotating laser level. The distances to the left and right edges of the sandbar (along a transect parallel to the channel cross section) from each sample point were measured with a laser range finder.

Two bank-material samples were collected at each sampling location. Bank-sampling locations were selected based on three general criteria: (1) the bank section could not include, or be affected by, revetments or structures such as riprap, jetties, or coarse debris; (2) the bank was vertical or nearly vertical, allowing for easy access to the full bank stratum; and (3) either the vegetation on top of the bank was well established, or the bank stratigraphy itself clearly indicated that the stratum incorporated both channel and overbank sediments from several flow events. Once a bank-sampling location was identified, the bank was "cleaned" with a trowel and square shovel. "Cleaning" involved removing roots, bank sluff, and ravel, and scraping the face of the bank with the trowel or shovel to expose the in-place sediments. This was necessary because often the base of the bank appeared to be fine-grained sediment, but the cleaning procedure revealed it to be slope ravel. Once the bank was cleaned, it was divided vertically into two sample intervals based on textural differences in the sediment. In most cases, a distinct break in textures was present, usually between coarser sediment near the base and the finer sediment in the uppermost portion. In some cases, multiple textural layers were present, and in such instances the bank-sampling section was divided at less obvious textural breaks, often near the halfway point on the bank. An integrated sample of each section was taken by scraping the square shovel vertically along the cleaned bank, while ensuring that the rate of sediment removal was approximately equal across all strata. This method yields samples in which all strata are represented in proportion to their presence at the exposed section. The vertical location of the top of each sampled interval and the total height of the bank were measured relative to the water surface with a graduated wading rod. In cases where the sampled bank was a significant distance away from the water surface, a hand level was used in conjunction with the graduated wading rod to obtain height measurements.

Sediment samples were collected between July 23 and August 13,2010. The sample locations and associated measurements are shown in tables 2-5. Sediment samples were delivered to the USACE, Omaha District office, for laboratory processing. Grain-size-distribution results are available upon request at the USACE, Omaha District.

\section{Quality Assurance}

To document the reach-scale variation in grain size within an individual sample site, replicate samples of bed material, sandbar material, and bank material were collected. One replicate sample of bed material, 1 replicate sample of bank material, and 2 replicate samples of sandbar material were collected within each of the 3 main-stem sections (corresponding to reach-identifier prefixes, "1" to "3;" fig. 1). These samples were collected between 100-300 ft upstream or downstream from the primary samples. Bed-material replicate samples were collected as a paired replicate of one of the primary bedmaterial subsamples and do not replicate the entire composited primary sample.

To provide some assurance that similar sediment samples were collected by the US BMH-53 and the US BMH-60, as well as to provide some indication of local-scale variation in grain size between samples collected by a single sampler, 6 samples were collected on a sandbar within a few inches from each other, 3 were collected with the US BMH-53, and 3 with the US BMH-60. Laboratory determinations of particlesize distributions of quality-assurance samples were done by dry sieve analysis at the USGS Kentucky Water Science Center Sediment Laboratory (Guy, 1969). The results are shown in figure 4, and the plotted data are shown in the appendix. Except for the finest sieve size, the results for all samples were within 17 percent of the overall mean percentage finer than each indicated grain size, and variability was less than 6 percent for grain size of 0.5 millimeters or larger.

\section{Channel-Geometry Data}

Platte River bank heights ranged from $2.2 \mathrm{ft}$ above the local water surface at reach UA (table 3 ) to $6.2 \mathrm{ft}$ at reaches $2 \mathrm{~B}$ and $3 \mathrm{~B}$ (table 3 ). Platte River sandbar heights, relative to the water surface, ranged from $0.4 \mathrm{ft}$ at reach UA to $4.8 \mathrm{ft}$ at reach $3 \mathrm{~B}$ (table 4 ). The widest sandbar measured was $1,308 \mathrm{ft}$ wide at reach $1 \mathrm{C}$ (table 4 ), and the narrowest sandbar measured was $15 \mathrm{ft}$ wide in reach UB (table 4). Sandbar widths were measured along a transverse line at the channel cross section where the sandbar-material sample was collected, so the measured width does not necessarily reflect the maximum width of the sandbar. Similarly, sandbar heights reported were the maximum height only locally where sandbar-material samples were collected, not necessarily representative of reach or river extremes. Total bank height relative to the water surface for tributary streams varied from 3.6 to $10.8 \mathrm{ft}$ for Loup River sites, 9.5 to $17.2 \mathrm{ft}$ for Shell Creek sites, 5.4 to $9.1 \mathrm{ft}$ for Elkhorn River sites, and 8.2 to $17.3 \mathrm{ft}$ for Salt Creek sites. Platte River current velocity (table 5) varied in relation to water depth, from $0.43 \mathrm{fps}$ in $0.5 \mathrm{ft}$ of water (reach 1C) to $3.29 \mathrm{fps}$ in $2.4 \mathrm{ft}$ of water (reach 1E). 

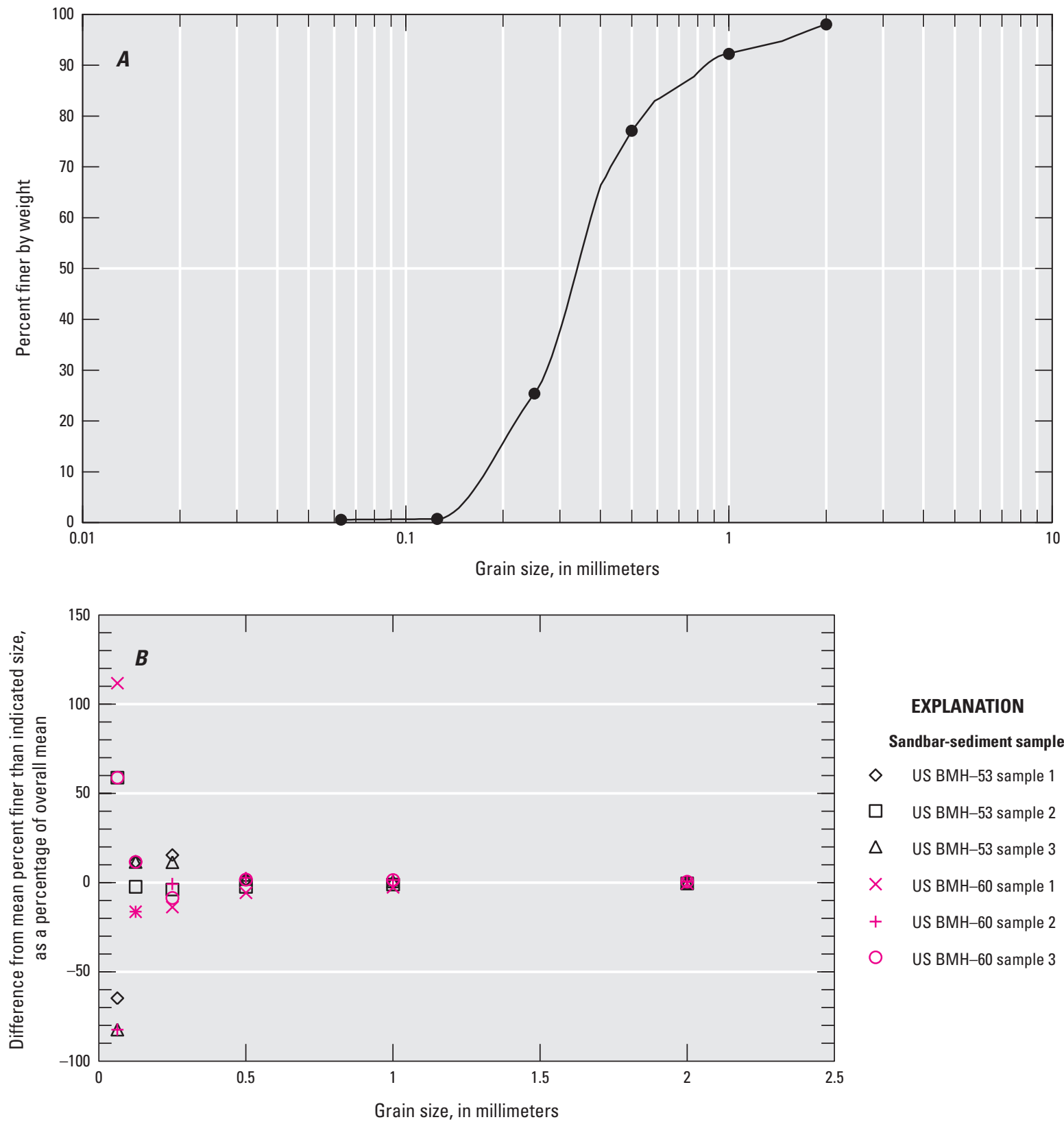

Figure 4. Graphs showing grain-size information for six sandbar-sediment samples collected with two different samplers at a single location on the lower Platte River, Nebraska, 2010 
Table 2. Summary of sediment-sampling sites in lower Platte River watershed, Nebraska, 2010.

[Reach identifiers correspond to figure 1; NA, not applicable]

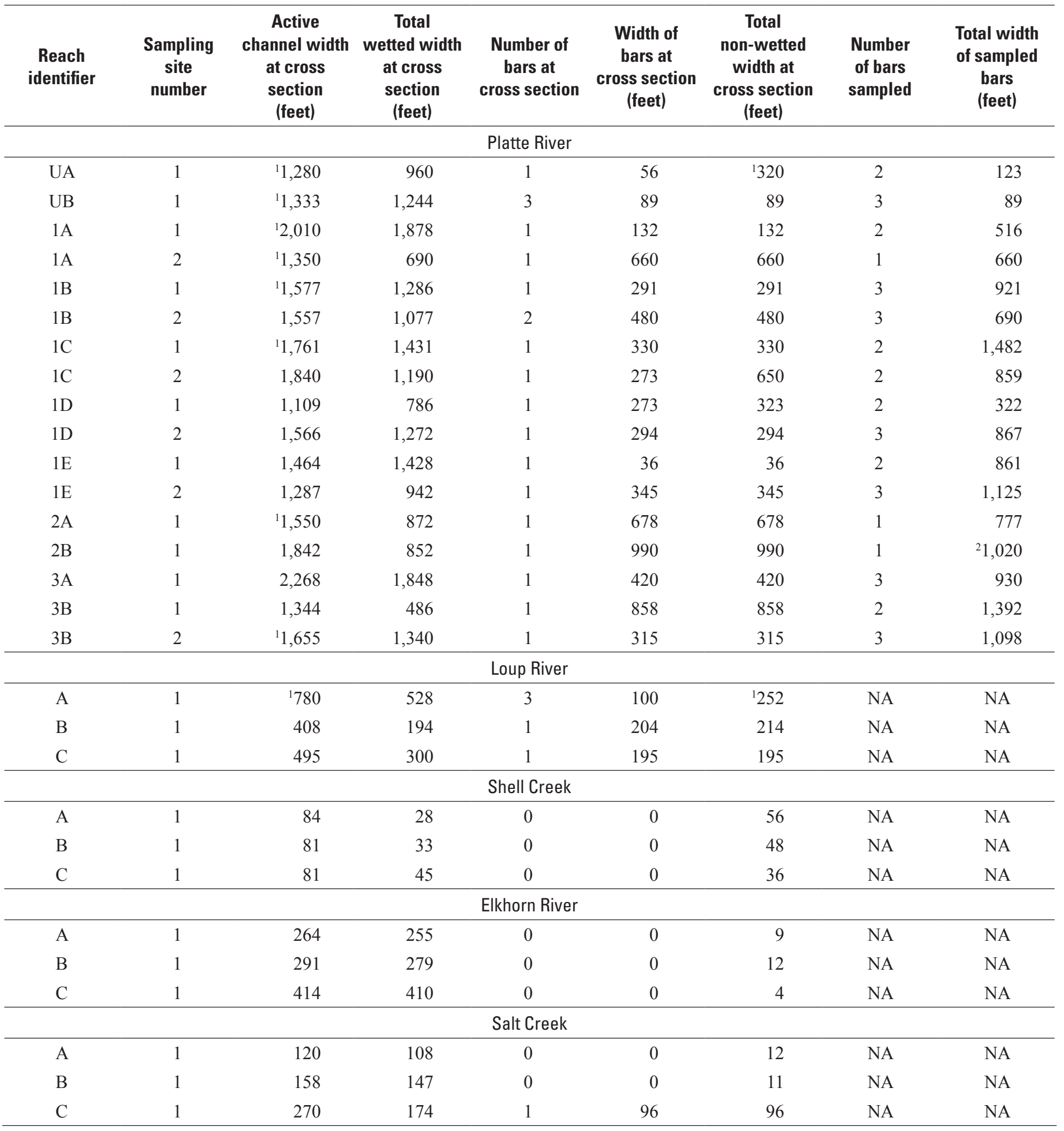

${ }^{1}$ Estimated using georeferenced 2007 National Agricultural Imagery Program (Farm Service Agency, 2007) digital orthophotographs.

${ }^{2}$ Estimated based on distances measured to nearby features. 
Table 3. Sample locations and data associated with bank-sediment samples, lower Platte River watershed, Nebraska, 2010.

[Reach identifiers correspond to figure 1; Sample site number " 1 " is most upstream and sample site number "2" is most downstream within indicated reach]

\begin{tabular}{|c|c|c|c|c|c|c|c|c|c|c|c|c|}
\hline $\begin{array}{l}\text { Sample } \\
\text { identifier } \\
\text { code }\end{array}$ & $\begin{array}{l}\text { Reach } \\
\text { identifier }\end{array}$ & $\begin{array}{l}\text { Sampling } \\
\text { site } \\
\text { number }\end{array}$ & $\begin{array}{l}\text { Sample } \\
\text { number }\end{array}$ & Date & Time & Latitude & Longitude & $\begin{array}{l}\text { Horizontal } \\
\text { accuracy } \\
\text { (feet) }\end{array}$ & $\begin{array}{c}\text { Distance } \\
\text { from nearest } \\
\text { edge of water } \\
\text { (feet) }\end{array}$ & $\begin{array}{l}\text { Total bank } \\
\text { height rela- } \\
\text { tive to water } \\
\text { surface } \\
\text { (feet) }\end{array}$ & $\begin{array}{c}\text { Bank angle } \\
\text { (degrees) }\end{array}$ & $\begin{array}{l}\text { Sampled inter- } \\
\text { val, as height } \\
\text { relative to } \\
\text { water surface } \\
\text { (feet) }\end{array}$ \\
\hline \multicolumn{13}{|c|}{ Platte River } \\
\hline 2010006 & UA & 1 & 1 & $7 / 28 / 2010$ & $14: 40$ & $41^{\circ} 20^{\prime} 31.57^{\prime \prime}$ & $97^{\circ} 34^{\prime} 12.50^{\prime \prime}$ & 17 & 0 & 2.2 & 45 & $0.0-2.0$ \\
\hline 2010007 & UA & 1 & 2 & $7 / 28 / 2010$ & $14: 50$ & $41^{\circ} 20^{\prime} 31.57^{\prime \prime}$ & $97^{\circ} 34^{\prime} 12.50^{\prime \prime}$ & 17 & 0 & 2.2 & 45 & $2.0-2.2$ \\
\hline 2010013 & UB & 1 & 1 & $7 / 28 / 2010$ & $16: 00$ & $41^{\circ} 23^{\prime} 25.43^{\prime \prime}$ & $97^{\circ} 23^{\prime} 58.75^{\prime \prime}$ & 15 & 0 & 2.9 & 70 & $.0-.6$ \\
\hline 2010014 & UB & 1 & 2 & $7 / 28 / 2010$ & $16: 10$ & $41^{\circ} 23^{\prime} 25.43^{\prime \prime}$ & $97^{\circ} 23^{\prime} 58.75^{\prime \prime}$ & 15 & 0 & 2.9 & 70 & $.6-2.9$ \\
\hline 2010020 & $1 \mathrm{~A}$ & 1 & 1 & $7 / 29 / 2010$ & $16: 20$ & $41^{\circ} 22^{\prime} 49.12^{\prime \prime}$ & $97^{\circ} 13 ' 50.05^{\prime \prime}$ & 14 & 0 & 3.2 & 90 & $.0-2.5$ \\
\hline 2010021 & $1 \mathrm{~A}$ & 1 & 2 & $7 / 29 / 2010$ & $16: 30$ & $41^{\circ} 22^{\prime} 49.12^{\prime \prime}$ & $97^{\circ} 13^{\prime} 50.05^{\prime \prime}$ & 14 & 0 & 3.2 & 90 & $2.5-3.2$ \\
\hline 2010027 & $1 \mathrm{~A}$ & 2 & 1 & $7 / 29 / 2010$ & $13: 30$ & $41^{\circ} 23^{\prime} 01.17^{\prime \prime}$ & $97^{\circ} 09^{\prime} 18.99^{\prime \prime}$ & 9 & 660 & 5.6 & 55 & $.0-1.5$ \\
\hline 2010028 & $1 \mathrm{~A}$ & 2 & 2 & $7 / 29 / 2010$ & $13: 40$ & $41^{\circ} 23^{\prime} 01.17^{\prime}$ & $97^{\circ} 09^{\prime} 18.99^{\prime \prime}$ & 9 & 660 & 5.6 & 55 & $1.5-5.6$ \\
\hline 2010034 & 1B & 1 & 1 & $7 / 30 / 2010$ & $12: 12$ & $41^{\circ} 26^{\prime} 46.20^{\prime \prime}$ & $96^{\circ} 57^{\prime} 26.65^{\prime \prime}$ & 15 & 0 & 4.7 & 90 & $.0-2.4$ \\
\hline 2010035 & 1B & 1 & 2 & $7 / 30 / 2010$ & $12: 20$ & $41^{\circ} 26^{\prime} 46.20^{\prime \prime}$ & $96^{\circ} 57^{\prime} 26.65^{\prime \prime}$ & 15 & 0 & 4.7 & 90 & $2.4-4.7$ \\
\hline 2010043 & 1B & 2 & 1 & $7 / 30 / 2010$ & $13: 40$ & $41^{\circ} 27^{\prime} 18.19^{\prime \prime}$ & $96^{\circ} 52^{\prime} 30.76^{\prime \prime}$ & 15 & 0 & 4.8 & 90 & $.0-2.9$ \\
\hline 2010044 & 1B & 2 & 2 & $7 / 30 / 2010$ & $13: 50$ & $41^{\circ} 27^{\prime} 18.19^{\prime \prime}$ & $96^{\circ} 52^{\prime} 30.76^{\prime \prime}$ & 15 & 0 & 4.8 & 90 & $2.9-4.7$ \\
\hline 2010053 & $1 \mathrm{C}$ & 1 & 1 & $7 / 27 / 2010$ & $11: 30$ & $41^{\circ} 25^{\prime} 53.67^{\prime \prime}$ & $96^{\circ} 40^{\prime} 15.07 ”$ & 16 & 0 & 3.4 & 90 & $.0-.7$ \\
\hline 2010054 & $1 \mathrm{C}$ & 1 & 2 & $7 / 27 / 2010$ & $11: 40$ & $41^{\circ} 25^{\prime} 53.67^{\prime \prime}$ & $96^{\circ} 40^{\prime} 15.07 \prime$ & 16 & 0 & 3.4 & 90 & $.7-1.4$ \\
\hline 2010055 & $1 \mathrm{C}$ & 1 & 3 & $7 / 27 / 2010$ & $11: 40$ & $41^{\circ} 25^{\prime} 53.67^{\prime \prime}$ & $96^{\circ} 40^{\prime} 15.07 ’$ & 16 & 0 & 3.4 & 90 & $1.4-3.4$ \\
\hline 2010061 & $1 \mathrm{C}$ & 2 & 1 & $7 / 27 / 2010$ & $14: 52$ & $41^{\circ} 26^{\prime} 14.60^{\prime \prime}$ & $96^{\circ} 35^{\prime} 57.78^{\prime \prime}$ & 12 & 0 & 3.0 & 90 & $.0-1.1$ \\
\hline 2010062 & $1 \mathrm{C}$ & 2 & 2 & $7 / 27 / 2010$ & $15: 00$ & $41^{\circ} 26^{\prime} 14.60^{\prime \prime}$ & $96^{\circ} 35^{\prime} 57.78^{\prime \prime}$ & 12 & 0 & 3.0 & 90 & $1.1-3.0$ \\
\hline 2010068 & $1 \mathrm{D}$ & 1 & 1 & $7 / 26 / 2010$ & $12: 05$ & $41^{\circ} 22^{\prime} 13.88^{\prime \prime}$ & $96^{\circ} 25^{\prime} 51.55^{\prime \prime}$ & 8 & 0 & 3.0 & 80 & $.0-1.7$ \\
\hline 2010069 & $1 \mathrm{D}$ & 1 & 2 & $7 / 26 / 2010$ & $12: 10$ & $41^{\circ} 22^{\prime} 13.88^{\prime \prime}$ & $96^{\circ} 25^{\prime} 51.55^{\prime \prime}$ & 8 & 0 & 3.0 & 80 & $1.7-3.0$ \\
\hline 2010075 & $1 \mathrm{D}$ & 2 & 1 & $8 / 10 / 2010$ & $10: 55$ & $41^{\circ} 19^{\prime} 22.85^{\prime \prime}$ & $96^{\circ} 24^{\prime} 16.35^{\prime \prime}$ & 11 & 0 & 3.9 & 90 & $1.0-3.9$ \\
\hline 2010076 & $1 \mathrm{D}$ & 2 & 2 & $8 / 10 / 2010$ & $10: 48$ & $41^{\circ} 19^{\prime} 22.85^{\prime \prime}$ & $96^{\circ} 24^{\prime} 16.35^{\prime \prime}$ & 11 & 0 & 3.9 & 90 & $.0-1.0$ \\
\hline 2010082 & $1 \mathrm{E}$ & 1 & 1 & $8 / 10 / 2010$ & $16: 35$ & $41^{\circ} 13^{\prime} 03.53^{\prime \prime}$ & $96^{\circ} 21^{\prime} 22.91 ”$ & 15 & 0 & 3.2 & 90 & $.0-1.2$ \\
\hline 2010083 & $1 \mathrm{E}$ & 1 & 2 & $8 / 10 / 2010$ & $16: 45$ & $41^{\circ} 13^{\prime} 03.53^{\prime \prime}$ & $96^{\circ} 21^{\prime} 22.91 ”$ & 15 & 0 & 3.2 & 90 & $1.2-3.2$ \\
\hline 2010089 & $1 \mathrm{E}$ & 2 & 1 & $8 / 11 / 2010$ & $10: 55$ & $41^{\circ} 11^{\prime} 15.30^{\prime \prime}$ & $96^{\circ} 19^{\prime} 39.98^{\prime \prime}$ & 16 & 0 & 4.3 & 90 & $.0-1.9$ \\
\hline 2010090 & $1 \mathrm{E}$ & 2 & 2 & $8 / 11 / 2010$ & $11: 05$ & $41^{\circ} 11^{\prime} 15.30 ”$ & $96^{\circ} 19^{\prime} 39.98^{\prime \prime}$ & 16 & 0 & 4.3 & 90 & $1.9-4.3$ \\
\hline 2010091 & $1 \mathrm{E}$ & ${ }^{12}$ & 1 & $8 / 11 / 2010$ & $13: 00$ & $41^{\circ} 11^{\prime} 16.85^{\prime \prime}$ & $96^{\circ} 19^{\prime} 43.13^{\prime \prime}$ & 16 & 0 & 4.3 & 90 & $.0-2.3$ \\
\hline 2010097 & $2 \mathrm{~A}$ & 1 & 1 & $8 / 11 / 2010$ & $14: 40$ & $41^{\circ} 06^{\prime} 13.23 ”$ & $96^{\circ} 19^{\prime} 53.15^{\prime \prime}$ & 12 & 0 & 4.3 & 90 & $.0-2.1$ \\
\hline 2010098 & $2 \mathrm{~A}$ & 1 & 2 & $8 / 11 / 2010$ & $14: 50$ & $41^{\circ} 06^{\prime} 13.23^{\prime \prime}$ & $96^{\circ} 19^{\prime} 53.15^{\prime \prime}$ & 12 & 0 & 4.3 & 90 & $2.1-4.3$ \\
\hline 2010106 & $2 \mathrm{~B}$ & 1 & 1 & $8 / 11 / 2010$ & $16: 53$ & $41^{\circ} 04^{\prime} 32.79^{\prime \prime}$ & $96^{\circ} 19^{\prime} 56.44^{\prime \prime}$ & 11 & 0 & 6.2 & 90 & $.0-2.9$ \\
\hline
\end{tabular}


Table 3. Sample locations and data associated with bank-sediment samples, lower Platte River watershed, Nebraska, 2010.—Continued

[Reach identifiers correspond to figure 1; Sample site number "1" is most upstream and sample site number " 2 " is most downstream within indicated reach]

\begin{tabular}{|c|c|c|c|c|c|c|c|c|c|c|c|c|}
\hline $\begin{array}{l}\text { Sample } \\
\text { identifier } \\
\text { code }\end{array}$ & $\begin{array}{c}\text { Reach } \\
\text { identifier }\end{array}$ & $\begin{array}{l}\text { Sampling } \\
\text { site } \\
\text { number }\end{array}$ & $\begin{array}{l}\text { Sample } \\
\text { number }\end{array}$ & Date & Time & Latitude & Longitude & $\begin{array}{c}\text { Horizontal } \\
\text { accuracy } \\
\text { (feet) }\end{array}$ & $\begin{array}{c}\text { Distance } \\
\text { from nearest } \\
\text { edge of water } \\
\text { (feet) }\end{array}$ & $\begin{array}{l}\text { Total bank } \\
\text { height rela- } \\
\text { tive to water } \\
\text { surface } \\
\text { (feet) }\end{array}$ & $\begin{array}{c}\text { Bank angle } \\
\text { (degrees) }\end{array}$ & $\begin{array}{l}\text { Sampled inter- } \\
\text { val, as height } \\
\text { relative to } \\
\text { water surface } \\
\text { (feet) }\end{array}$ \\
\hline \multicolumn{13}{|c|}{ Platte River-Continued } \\
\hline 2010107 & $2 \mathrm{~B}$ & 1 & 2 & $8 / 11 / 2010$ & $16: 59$ & $41^{\circ} 04^{\prime} 32.79^{\prime \prime}$ & $96^{\circ} 19^{\prime} 56.44^{\prime \prime}$ & 11 & 0 & 6.2 & 90 & $2.9-6.2$ \\
\hline 2010111 & $2 \mathrm{~B}$ & ${ }^{1} 1$ & 1 & $8 / 11 / 2010$ & $17: 10$ & $41^{\circ} 04^{\prime} 35.73 ”$ & $96^{\circ} 19^{\prime} 57.87^{\prime \prime}$ & 11 & 0 & 5.7 & 90 & $.0-1.6$ \\
\hline 2010117 & $3 \mathrm{~A}$ & 1 & 1 & $8 / 12 / 2010$ & $11: 55$ & $41^{\circ} 01^{\prime} 08.95^{\prime \prime}$ & $96^{\circ} 14^{\prime} 55.68^{\prime \prime}$ & 20 & 0 & 4.7 & 90 & $.0-1.4$ \\
\hline 2010118 & $3 \mathrm{~A}$ & 1 & 2 & $8 / 12 / 2010$ & $12: 00$ & $41^{\circ} 01^{\prime} 08.95 "$ & $96^{\circ} 14^{\prime} 55.68^{\prime \prime}$ & 20 & 0 & 4.7 & 90 & $1.4-4.7$ \\
\hline 2010126 & $3 \mathrm{~B}$ & 1 & 1 & $8 / 12 / 2010$ & $15: 05$ & $41^{\circ} 03$ ' 17.52” & $96^{\circ} 05^{\prime} 50.63^{\prime \prime}$ & 16 & 0 & 5.5 & 90 & $.0-3.0$ \\
\hline 2010127 & $3 \mathrm{~B}$ & 1 & 2 & $8 / 12 / 2010$ & $15: 10$ & $41^{\circ} 03^{\prime} 17.52 ”$ & $96^{\circ} 05^{\prime} 50.63^{\prime \prime}$ & 16 & 0 & 5.5 & 90 & $3.0-5.5$ \\
\hline 2010131 & $3 \mathrm{~B}$ & ${ }^{1} 1$ & 1 & $8 / 12 / 2010$ & $15: 30$ & $41^{\circ} 03 ’ 16.81^{\prime \prime}$ & $96^{\circ} 05^{\prime} 55.47^{\prime \prime}$ & 20 & 0 & 6.2 & 90 & $.0-2.6$ \\
\hline 2010137 & $3 \mathrm{~B}$ & 2 & 1 & $8 / 13 / 2010$ & $10: 35$ & $41^{\circ} 03^{\prime} 30.19^{\prime \prime}$ & $95^{\circ} 57^{\prime} 21.99^{\prime \prime}$ & 17 & 0 & 4.7 & 30 & $.0-1.5$ \\
\hline 2010138 & 3B & 2 & 2 & $8 / 13 / 2010$ & $10: 45$ & $41^{\circ} 03^{\prime} 30.19$ ' & $95^{\circ} 57^{\prime} 21.99 ”$ & 17 & 0 & 4.7 & 30 & $1.5-4.7$ \\
\hline \multicolumn{13}{|c|}{ Loup River } \\
\hline 2010140 & A & 1 & 1 & $7 / 23 / 2010$ & $12: 15$ & $41^{\circ} 20^{\prime} 15.53 ”$ & $97^{\circ} 59^{\prime} 34.65^{\prime \prime}$ & 19 & 0 & 3.6 & 50 & $0.0-3.6$ \\
\hline 2010142 & B & 1 & 1 & $7 / 29 / 2010$ & $8: 26$ & $41^{\circ} 27^{\prime} 27.01^{\prime \prime}$ & $97^{\circ} 36^{\prime} 06.47^{\prime \prime}$ & 17 & 0 & 10.8 & 20 & $.0-6.9$ \\
\hline 2010143 & B & 1 & 2 & $7 / 29 / 2010$ & $8: 30$ & $41^{\circ} 27^{\prime} 27.01 ”$ & $97^{\circ} 36^{\prime} 06.47^{\prime \prime}$ & 17 & 0 & 10.8 & 20 & $6.9-10.8$ \\
\hline 2010145 & $\mathrm{C}$ & 1 & 1 & $7 / 29 / 2010$ & $10: 47$ & $41^{\circ} 24^{\prime} 01.71^{\prime \prime}$ & $97^{\circ} 19^{\prime} 38.61 ”$ & 21 & 0 & 6.1 & 60 & $.0-6.1$ \\
\hline \multicolumn{13}{|c|}{ Shell Creek } \\
\hline 2010147 & A & 1 & 1 & $8 / 20 / 2010$ & $11: 47$ & $41^{\circ} 31^{\prime} 33.13^{\prime \prime}$ & $97^{\circ} 16^{\prime} 52.72^{\prime \prime}$ & 24 & 0 & 15.2 & 45 & $\begin{array}{c}0.0-1.8 \\
13.4-15.2\end{array}$ \\
\hline 2010149 & B & 1 & 1 & $8 / 20 / 2010$ & $12: 15$ & $41^{\circ} 31^{\prime} 08.61^{\prime \prime}$ & $97^{\circ} 13^{\prime} 58.91 "$ & 23 & 6 & 17.2 & 55 & $\begin{array}{c}4.0-5.6 \\
12.2-14.2\end{array}$ \\
\hline 2010151 & $\mathrm{C}$ & 1 & 1 & $8 / 20 / 2010$ & $9: 50$ & $41^{\circ} 27^{\prime} 13.56 "$ & $97^{\circ} 00^{\prime} 07.24^{\prime \prime}$ & 17 & 36 & 9.5 & 90 & $2.4-9.5$ \\
\hline \multicolumn{13}{|c|}{ Elkhorn River } \\
\hline 2010153 & A & 1 & 1 & $8 / 19 / 2010$ & $15: 30$ & $41^{\circ} 27^{\prime} 13.98^{\prime \prime}$ & $96^{\circ} 22^{\prime} 11.51^{\prime \prime}$ & 19 & 1 & 6.7 & 76 & $0.0-3.8$ \\
\hline 2010155 & B & 1 & 1 & $8 / 19 / 2010$ & $13: 40$ & $41^{\circ} 21^{\prime} 01.16^{\prime \prime}$ & $96^{\circ} 17^{\prime} 30.54^{\prime \prime}$ & 16 & 2 & 9.1 & 52 & $.0-2.8$ \\
\hline 2010157 & $\mathrm{C}$ & 1 & 1 & $8 / 11 / 2010$ & $13: 48$ & $41^{\circ} 08^{\prime} 03.14^{\prime \prime}$ & $96^{\circ} 18^{\prime} 42.08^{\prime \prime}$ & 20 & 0 & 5.4 & 90 & $.0-5.4$ \\
\hline \multicolumn{13}{|c|}{ Salt Creek } \\
\hline 2010159 & A & 1 & 1 & $8 / 19 / 2010$ & $9: 30$ & $41^{\circ} 01^{\prime} 43.31^{\prime \prime}$ & $96^{\circ} 23^{\prime} 17.13^{\prime \prime}$ & 22 & 0 & 17.3 & 64 & $1.0-2.6$ \\
\hline 2010161 & B & 1 & 1 & $8 / 19 / 2010$ & $11: 50$ & $41^{\circ} 02^{\prime} 05.34$ ” & $96^{\circ} 22^{\prime} 03.99^{\prime \prime}$ & 25 & 6 & 13.6 & 48 & $1.7-5.9$ \\
\hline 2010163 & $\mathrm{C}$ & 1 & 1 & $8 / 12 / 2010$ & $10: 47$ & $41^{\circ} 02^{\prime} 26.36^{\prime \prime}$ & $96^{\circ} 19^{\prime} 24.76^{\prime \prime}$ & 25 & 0 & 8.2 & 90 & $.0-5.3$ \\
\hline
\end{tabular}

${ }^{1}$ Sample is a replicate of sample same-numbered, but was located 100-300 feet upstream or downstream from primary sample location. 
Table 4. Sample locations and data associated with sandbar-sediment samples, lower Platte River, Nebraska, 2010.

[Reach identifiers correspond to figure 1; Sample site number "1" is most upstream and sample site number " 2 " is most downstream within indicated reach]

\begin{tabular}{|c|c|c|c|c|c|c|c|c|c|c|c|c|c|}
\hline \multirow[b]{2}{*}{$\begin{array}{c}\text { Sample } \\
\text { identifier } \\
\text { code }\end{array}$} & \multirow[b]{2}{*}{$\begin{array}{l}\text { Reach } \\
\text { Identifier }\end{array}$} & \multirow[b]{2}{*}{$\begin{array}{l}\text { Sampling } \\
\text { site } \\
\text { number }\end{array}$} & \multirow[b]{2}{*}{$\begin{array}{l}\text { Sample } \\
\text { number }\end{array}$} & \multirow[b]{2}{*}{ Date } & \multirow[b]{2}{*}{ Time } & \multirow[b]{2}{*}{ Latitude } & \multirow[b]{2}{*}{ Longitude } & \multirow[b]{2}{*}{$\begin{array}{c}\text { Horizontal } \\
\text { accuracy } \\
\text { (feet) }\end{array}$} & \multirow{2}{*}{$\begin{array}{c}\text { Bar height } \\
\text { above } \\
\text { water } \\
\text { surface } \\
\text { elevation } \\
\text { (feet) }\end{array}$} & \multicolumn{4}{|c|}{$\begin{array}{l}\text { Distances measured along line of transverse } \\
\text { section at bar }\end{array}$} \\
\hline & & & & & & & & & & $\begin{array}{l}\text { Bar width } \\
\text { (feet) }\end{array}$ & $\begin{array}{c}\text { Distance } \\
\text { from left } \\
\text { bank } \\
\text { (feet) }\end{array}$ & $\begin{array}{c}\text { Distance } \\
\text { from left } \\
\text { edge of } \\
\text { bar } \\
\text { (feet) }\end{array}$ & $\begin{array}{c}\text { Distance } \\
\text { from right } \\
\text { edge of } \\
\text { bar } \\
\text { (feet) }\end{array}$ \\
\hline 2010003 & UA & 1 & 1 & $7 / 28 / 2010$ & $12: 55$ & $41^{\circ} 20^{\prime} 27.75^{\prime \prime}$ & $97^{\circ} 34^{\prime} 13.54^{\prime \prime}$ & 14 & 0.4 & 93 & ${ }^{2} 315$ & 42 & 51 \\
\hline 2010004 & UA & 1 & 2 & $7 / 28 / 2010$ & $13: 03$ & $41^{\circ} 20^{\prime} 27.44^{\prime \prime}$ & $97^{\circ} 34^{\prime} 14.42^{\prime \prime}$ & 10 & .8 & 56 & ${ }^{2} 293$ & 20 & 36 \\
\hline 2010005 & UA & 1 & 3 & $7 / 28 / 2010$ & $13: 21$ & $41^{\circ} 20^{\prime} 28.67^{\prime \prime}$ & $97^{\circ} 34^{\prime} 04.30^{\prime \prime}$ & 16 & .7 & 30 & 525 & 10 & 20 \\
\hline 2010010 & UB & 1 & 1 & $7 / 28 / 2010$ & $16: 45$ & $41^{\circ} 23^{\prime} 21.90^{\prime \prime}$ & $97^{\circ} 24^{\prime} 04.69^{\prime \prime}$ & 11 & .8 & 15 & 123 & 5 & 10 \\
\hline 2010011 & UB & 1 & 2 & $7 / 28 / 2010$ & $17: 00$ & $41^{\circ} 23^{\prime} 22.37^{\prime \prime}$ & $97^{\circ} 23^{\prime} 54.54 \prime$ & 14 & .6 & 56 & 390 & 42 & 12 \\
\hline 2010012 & UB & 1 & 3 & $7 / 28 / 2010$ & 18:00 & $41^{\circ} 23^{\prime} 16.61^{\prime \prime}$ & $97^{\circ} 23^{\prime} 51.62 "$ & 16 & .9 & 20 & 1,005 & 10 & 10 \\
\hline 2010017 & $1 \mathrm{~A}$ & 1 & 1 & $7 / 29 / 2010$ & $17: 00$ & $41^{\circ} 22^{\prime} 52.75^{\prime \prime}$ & $97^{\circ} 13^{\prime} 46.43^{\prime \prime}$ & 16 & .5 & 132 & ${ }^{2} 1,640$ & 96 & 36 \\
\hline 2010018 & $1 \mathrm{~A}$ & 1 & 2 & $7 / 29 / 2010$ & $17: 52$ & $41^{\circ} 23^{\prime} 04.32^{\prime \prime}$ & $97^{\circ} 13^{\prime} 54.80^{\prime \prime}$ & 20 & 2.9 & 349 & ${ }^{2} 336$ & 10 & 339 \\
\hline 2010019 & $1 \mathrm{~A}$ & 1 & 3 & $7 / 29 / 2010$ & 18:01 & $41^{\circ} 23^{\prime} 03.67^{\prime \prime}$ & $97^{\circ} 13^{\prime} 57.83^{\prime \prime}$ & 15 & .7 & 384 & 390 & 174 & 210 \\
\hline 2010024 & $1 \mathrm{~A}$ & 2 & 1 & $7 / 29 / 2010$ & $13: 10$ & $41^{\circ} 22^{\prime} 57.13^{\prime \prime}$ & $97^{\circ} 09^{\prime} 15.67^{\prime \prime}$ & 12 & 2.6 & 660 & 255 & 255 & 405 \\
\hline 2010025 & $1 \mathrm{~A}$ & 2 & 2 & $7 / 29 / 2010$ & $14: 05$ & $41^{\circ} 22^{\prime} 57.78^{\prime \prime}$ & $97^{\circ} 09^{\prime} 05.03 "$ & 14 & 1.8 & 640 & 240 & 240 & 400 \\
\hline 2010026 & $1 \mathrm{~A}$ & 2 & 3 & $7 / 29 / 2010$ & $14: 15$ & $41^{\circ} 23^{\prime} 00.50^{\prime \prime}$ & $97^{\circ} 09^{\prime} 00.27^{\prime \prime}$ & 11 & .6 & 285 & 10 & 275 & 10 \\
\hline 2010031 & $1 \mathrm{~B}$ & 1 & 1 & $7 / 30 / 2010$ & $10: 39$ & $41^{\circ} 26^{\prime} 38.13^{\prime \prime}$ & $96^{\circ} 57^{\prime} 41.60^{\prime \prime}$ & 20 & 1.8 & 267 & 447 & 111 & 156 \\
\hline 2010032 & $1 \mathrm{~B}$ & 1 & 2 & $7 / 30 / 2010$ & $11: 30$ & $41^{\circ} 26^{\prime} 39.36^{\prime \prime}$ & $96^{\circ} 57^{\prime} 28.42 ”$ & 14 & 2.4 & 363 & 630 & 267 & 96 \\
\hline 2010033 & $1 \mathrm{~B}$ & 1 & 3 & $7 / 30 / 2010$ & $12: 57$ & $41^{\circ} 26^{\prime} 30.86^{\prime \prime}$ & $96^{\circ} 57^{\prime} 37.48^{\prime \prime}$ & 7 & 1.1 & 291 & 864 & 234 & 57 \\
\hline 2010040 & $1 \mathrm{~B}$ & 2 & 1 & $7 / 30 / 2010$ & $14: 30$ & $41^{\circ} 27^{\prime} 23.06^{\prime \prime}$ & $96^{\circ} 52^{\prime} 28.02^{\prime \prime}$ & 14 & 1.0 & 150 & 1,275 & 78 & 72 \\
\hline 2010041 & $1 \mathrm{~B}$ & 2 & 2 & $7 / 30 / 2010$ & $15: 15$ & $41^{\circ} 27^{\prime} 30.35^{\prime \prime}$ & $96^{\circ} 52^{\prime} 28.10^{\prime \prime}$ & 8 & .9 & 330 & 483 & 168 & 162 \\
\hline 2010042 & $1 \mathrm{~B}$ & 2 & 3 & $7 / 30 / 2010$ & $15: 30$ & $41^{\circ} 27^{\prime} 30.42^{\prime \prime}$ & $96^{\circ} 52^{\prime} 24.97 ”$ & 15 & 1.4 & 210 & 414 & 126 & 84 \\
\hline 2010046 & $1 \mathrm{~B}$ & 12 & 1 & $7 / 30 / 2010$ & $15: 20$ & $41^{\circ} 27^{\prime} 31.67^{\prime \prime}$ & $96^{\circ} 52^{\prime} 28.83^{\prime \prime}$ & 10 & 1.0 & 228 & 381 & 90 & 138 \\
\hline 2010047 & $1 \mathrm{~B}$ & 12 & 2 & $7 / 30 / 2010$ & $15: 38$ & $41^{\circ} 27^{\prime} 29.69^{\prime \prime}$ & $96^{\circ} 52^{\prime} 23.40^{\prime \prime}$ & 12 & 1.2 & 366 & 438 & 186 & 180 \\
\hline 2010050 & $1 \mathrm{C}$ & 1 & 1 & $7 / 27 / 2010$ & $13: 00$ & $41^{\circ} 25^{\prime} 47.27^{\prime \prime}$ & $96^{\circ} 40^{\prime} 15.64^{\prime \prime}$ & 22 & .5 & 330 & 645 & 120 & 210 \\
\hline 2010051 & $1 \mathrm{C}$ & 1 & 2 & $7 / 27 / 2010$ & $13: 20$ & $41^{\circ} 25^{\prime} 40.88^{\prime \prime}$ & $96^{\circ} 40^{\prime} 23.53^{\prime \prime}$ & 16 & 1.9 & 1,308 & 888 & 258 & 1,050 \\
\hline 2010052 & $1 \mathrm{C}$ & 1 & 3 & $7 / 27 / 2010$ & $14: 15$ & $41^{\circ} 25^{\prime} 39.69^{\prime \prime}$ & $96^{\circ} 40^{\prime} 10.89^{\prime \prime}$ & 7 & .6 & 204 & 1,440 & 114 & 60 \\
\hline 2010058 & $1 \mathrm{C}$ & 2 & 1 & $7 / 27 / 2010$ & $15: 55$ & $41^{\circ} 26^{\prime} 11.33^{\prime \prime}$ & $96^{\circ} 35^{\prime} 19.49^{\prime \prime}$ & 15 & .8 & 510 & 516 & 90 & 420 \\
\hline 2010059 & $1 \mathrm{C}$ & 2 & 2 & $7 / 27 / 2010$ & $16: 10$ & $41^{\circ} 26^{\prime} 11.11^{\prime \prime}$ & $96^{\circ} 35^{\prime} 24.85^{\prime \prime}$ & 16 & 2.3 & 650 & 690 & 300 & 350 \\
\hline 2010060 & $1 \mathrm{C}$ & 2 & 3 & $7 / 27 / 2010$ & $16: 40$ & $41^{\circ} 26^{\prime} 12.25^{\prime \prime}$ & $96^{\circ} 35^{\prime} 00.49^{\prime \prime}$ & 18 & 1.8 & 309 & 186 & 186 & 123 \\
\hline 2010065 & $1 \mathrm{D}$ & 1 & 1 & $7 / 26 / 2010$ & $12: 25$ & $41^{\circ} 22^{\prime} 11.40^{\prime \prime}$ & $96^{\circ} 25^{\prime} 50.77^{\prime \prime}$ & 10 & .6 & 49 & 171 & 36 & 13 \\
\hline 2010066 & $1 \mathrm{D}$ & 1 & 2 & $7 / 26 / 2010$ & $13: 00$ & $41^{\circ} 22^{\prime} 03.04^{\prime \prime}$ & $96^{\circ} 25^{\prime} 53.86^{\prime \prime}$ & 20 & .6 & 216 & 1,071 & 78 & 138 \\
\hline 2010067 & $1 \mathrm{D}$ & 1 & 3 & $7 / 26 / 2010$ & $13: 07$ & $41^{\circ} 22^{\prime} 01.27^{\prime \prime}$ & $96^{\circ} 25^{\prime} 53.59^{\prime \prime}$ & 20 & 2.0 & 273 & 1,080 & 180 & 93 \\
\hline
\end{tabular}


[Reach identifiers correspond to figure 1; Sample site number "1" is most upstream and sample site number " 2 " is most downstream within indicated reach]

\begin{tabular}{|c|c|c|c|c|c|c|c|c|c|c|c|c|c|}
\hline \multirow[b]{2}{*}{$\begin{array}{c}\text { Sample } \\
\text { identifier } \\
\text { code }\end{array}$} & \multirow[b]{2}{*}{$\begin{array}{l}\text { Reach } \\
\text { Identifier }\end{array}$} & \multirow[b]{2}{*}{$\begin{array}{l}\text { Sampling } \\
\text { site } \\
\text { number }\end{array}$} & \multirow[b]{2}{*}{$\begin{array}{l}\text { Sample } \\
\text { number }\end{array}$} & \multirow[b]{2}{*}{ Date } & \multirow[b]{2}{*}{ Time } & \multirow[b]{2}{*}{ Latitude } & \multirow[b]{2}{*}{ Longitude } & \multirow[b]{2}{*}{$\begin{array}{l}\text { Horizontal } \\
\text { accuracy } \\
\text { (feet) }\end{array}$} & \multirow{2}{*}{$\begin{array}{c}\text { Bar height } \\
\text { above } \\
\text { water } \\
\text { surface } \\
\text { elevation } \\
\text { (feet) }\end{array}$} & \multicolumn{4}{|c|}{$\begin{array}{c}\text { Distances measured along line of transverse } \\
\text { section at bar }\end{array}$} \\
\hline & & & & & & & & & & $\begin{array}{l}\text { Bar width } \\
\text { (feet) }\end{array}$ & $\begin{array}{c}\text { Distance } \\
\text { from left } \\
\text { bank } \\
\text { (feet) }\end{array}$ & $\begin{array}{c}\text { Distance } \\
\text { from left } \\
\text { edge of } \\
\text { bar } \\
\text { (feet) }\end{array}$ & $\begin{array}{c}\text { Distance } \\
\text { from right } \\
\text { edge of } \\
\text { bar } \\
\text { (feet) }\end{array}$ \\
\hline 2010072 & 1D & 2 & 1 & $8 / 10 / 2010$ & $10: 05$ & $41^{\circ} 19^{\prime} 19.37^{\prime \prime}$ & $96^{\circ} 24^{\prime} 20.51^{\prime \prime}$ & 15 & 2.2 & 306 & 333 & 174 & 132 \\
\hline 2010073 & $1 \mathrm{D}$ & 2 & 2 & $8 / 10 / 2010$ & $12: 27$ & $41^{\circ} 19^{\prime} 24.12^{\prime \prime}$ & $96^{\circ} 24^{\prime} 32.91 "$ & 14 & 1.6 & 294 & 1,260 & 129 & 165 \\
\hline 2010074 & $1 \mathrm{D}$ & 2 & 3 & $8 / 10 / 2010$ & $12: 55$ & $41^{\circ} 19^{\prime} 35.84 ”$ & $96^{\circ} 24^{\prime} 25.93^{\prime \prime}$ & 15 & 2.1 & 267 & 540 & 111 & 156 \\
\hline 2010079 & $1 \mathrm{E}$ & 1 & 1 & $8 / 10 / 2010$ & $14: 50$ & $41^{\circ} 13^{\prime} 06.73^{\prime \prime}$ & $96^{\circ} 21^{\prime} 28.18^{\prime \prime}$ & 14 & 1.8 & 825 & 686 & 480 & 345 \\
\hline 2010080 & $1 \mathrm{E}$ & 1 & 2 & $8 / 10 / 2010$ & $15: 05$ & $41^{\circ} 12^{\prime} 55.33^{\prime \prime}$ & $96^{\circ} 21^{\prime} 24.34^{\prime \prime}$ & 15 & 3.3 & 654 & 375 & 204 & 450 \\
\hline 2010081 & $1 \mathrm{E}$ & 1 & 3 & $8 / 10 / 2010$ & $15: 51$ & $41^{\circ} 13^{\prime} 09.14 "$ & $96^{\circ} 21^{\prime} 44.11^{\prime \prime}$ & 15 & 2.4 & 36 & 1,152 & 18 & 18 \\
\hline 2010086 & $1 \mathrm{E}$ & 2 & 1 & $8 / 11 / 2010$ & $12: 01$ & $41^{\circ} 11^{\prime} 02.64 ”$ & $96^{\circ} 19^{\prime} 28.62^{\prime \prime}$ & 16 & 3.0 & 489 & 336 & 36 & 453 \\
\hline 2010087 & $1 \mathrm{E}$ & 2 & 2 & $8 / 11 / 2010$ & $12: 22$ & $41^{\circ} 11^{\prime} 15.34 "$ & $96^{\circ} 19^{\prime} 24.78^{\prime \prime}$ & 11 & 2.0 & 291 & 234 & 234 & 57 \\
\hline 2010088 & $1 \mathrm{E}$ & 2 & 3 & $8 / 11 / 2010$ & $12: 50$ & $41^{\circ} 11^{\prime} 17.20^{\prime \prime}$ & $96^{\circ} 19^{\prime} 37.26^{\prime \prime}$ & 15 & 2.6 & 345 & 990 & 309 & 36 \\
\hline 2010094 & $2 \mathrm{~A}$ & 1 & 1 & $8 / 11 / 2010$ & $15: 30$ & $41^{\circ} 05^{\prime} 58.31^{\prime \prime}$ & $96^{\circ} 19^{\prime} 54.63 "$ & 16 & 4.0 & 678 & 408 & 408 & 270 \\
\hline 2010095 & $2 \mathrm{~A}$ & 1 & 2 & $8 / 11 / 2010$ & $16: 00$ & $41^{\circ} 05^{\prime} 54.16^{\prime \prime}$ & $96^{\circ} 20^{\prime} 03.32^{\prime \prime}$ & 20 & 4.1 & 777 & 615 & 615 & 162 \\
\hline 2010096 & $2 \mathrm{~A}$ & 1 & 3 & $8 / 11 / 2010$ & $16: 08$ & $41^{\circ} 05^{\prime} 51.01^{\prime \prime}$ & $96^{\circ} 20^{\prime} 03.52^{\prime \prime}$ & 14 & 4.0 & 663 & 519 & 519 & 144 \\
\hline 2010103 & $2 \mathrm{~B}$ & 1 & 1 & $8 / 11 / 2010$ & $18: 06$ & $41^{\circ} 04^{\prime} 27.17^{\prime \prime}$ & $96^{\circ} 20^{\prime} 02.21^{\prime \prime}$ & 9 & 2.0 & 270 & ${ }^{2} 555$ & 162 & 108 \\
\hline 2010104 & $2 \mathrm{~B}$ & 1 & 2 & $8 / 11 / 2010$ & $18: 30$ & $41^{\circ} 04^{\prime} 35.87^{\prime \prime}$ & $96^{\circ} 20^{\prime} 20.74$ ' & 10 & 3.5 & ${ }^{2} 1,020$ & 1,560 & 2912 & 108 \\
\hline 2010105 & $2 \mathrm{~B}$ & 1 & 3 & $8 / 11 / 2010$ & $19: 10$ & $41^{\circ} 04^{\prime} 35.62 ”$ & $96^{\circ} 20^{\prime} 05.72^{\prime \prime}$ & 17 & 3.7 & 2996 & 603 & 105 & ${ }^{2} 891$ \\
\hline 2010109 & $2 \mathrm{~B}$ & ${ }^{1} 1$ & 1 & $8 / 11 / 2010$ & $18: 40$ & $41^{\circ} 04^{\prime} 37.46^{\prime \prime}$ & $96^{\circ} 20^{\prime} 20.86^{\prime \prime}$ & 12 & 2.6 & ${ }^{2} 990$ & ${ }^{2} 1,512$ & ${ }^{2} 864$ & 126 \\
\hline 2010110 & $2 \mathrm{~B}$ & ${ }^{1} 1$ & 2 & $8 / 11 / 2010$ & $19: 17$ & $41^{\circ} 04^{\prime} 34.41^{\prime \prime}$ & $96^{\circ} 20^{\prime} 04.43^{\prime \prime}$ & 10 & 3.6 & ${ }^{2} 951$ & 603 & 60 & ${ }^{2} 891$ \\
\hline 2010114 & $3 \mathrm{~A}$ & 1 & 1 & $8 / 12 / 2010$ & $12: 25$ & $41^{\circ} 01^{\prime} 00.16^{\prime \prime}$ & $96^{\circ} 14^{\prime} 46.46^{\prime \prime}$ & 8 & 3.0 & 420 & 471 & 168 & 252 \\
\hline 2010115 & $3 \mathrm{~A}$ & 1 & 2 & $8 / 12 / 2010$ & $13: 05$ & $41^{\circ} 00^{\prime} 51.78^{\prime \prime}$ & $96^{\circ} 14^{\prime} 37.07^{\prime \prime}$ & 15 & 1.1 & 315 & 483 & 81 & 234 \\
\hline 2010116 & $3 \mathrm{~A}$ & 1 & 3 & $8 / 12 / 2010$ & $13: 40$ & $41^{\circ} 00^{\prime} 50.57^{\prime \prime}$ & $96^{\circ} 15^{\prime} 04.74^{\prime \prime}$ & 15 & 2.1 & 195 & 1,938 & 48 & 147 \\
\hline 2010123 & $3 \mathrm{~B}$ & 1 & 1 & $8 / 12 / 2010$ & $16: 15$ & $41^{\circ} 03^{\prime} 07.08^{\prime \prime}$ & $96^{\circ} 05^{\prime} 53.92^{\prime \prime}$ & 10 & 3.2 & 336 & 1,014 & 105 & 231 \\
\hline 2010124 & $3 \mathrm{~B}$ & 1 & 2 & $8 / 12 / 2010$ & $17: 05$ & $41^{\circ} 03$ ' 16.16” & $96^{\circ} 05^{\prime} 10.64^{\prime \prime}$ & 18 & 4.5 & 858 & 606 & 120 & 738 \\
\hline 2010125 & $3 \mathrm{~B}$ & 1 & 3 & $8 / 12 / 2010$ & $17: 30$ & $41^{\circ} 03^{\prime} 14.22^{\prime \prime}$ & $96^{\circ} 05^{\prime} 28.65^{\prime \prime}$ & 16 & 2.0 & 1,056 & 801 & 267 & 789 \\
\hline 2010129 & $3 \mathrm{~B}$ & ${ }^{1} 1$ & 1 & $8 / 12 / 2010$ & $16: 20$ & $41^{\circ} 03^{\prime} 07.68^{\prime \prime}$ & $96^{\circ} 05^{\prime} 52.18^{\prime \prime}$ & 14 & 3.3 & 378 & 990 & 156 & 222 \\
\hline 2010130 & $3 \mathrm{~B}$ & ${ }^{1} 1$ & 2 & $8 / 12 / 2010$ & $17: 15$ & $41^{\circ} 03^{\prime} 15.13 ”$ & $96^{\circ} 05^{\prime} 12.54^{\prime \prime}$ & 14 & 4.3 & 798 & 1,008 & 150 & 648 \\
\hline 2010134 & $3 \mathrm{~B}$ & 2 & 1 & $8 / 13 / 2010$ & $11: 20$ & $41^{\circ} 03^{\prime} 30.65^{\prime \prime}$ & $95^{\circ} 57^{\prime} 29.73^{\prime \prime}$ & 19 & 1.4 & 183 & 1,611 & 90 & 93 \\
\hline 2010135 & $3 \mathrm{~B}$ & 2 & 2 & $8 / 13 / 2010$ & $11: 40$ & $41^{\circ} 03^{\prime} 39.58^{\prime \prime}$ & $95^{\circ} 57^{\prime} 26.05^{\prime \prime}$ & 18 & 2.4 & 315 & 531 & 54 & 261 \\
\hline 2010136 & $3 \mathrm{~B}$ & 2 & 3 & $8 / 13 / 2010$ & $12: 30$ & $41^{\circ} 03 ’ 37.09 ”$ & $95^{\circ} 58^{\prime} 01.38^{\prime \prime}$ & 8 & 4.8 & 600 & 420 & 420 & 180 \\
\hline
\end{tabular}

${ }^{1}$ Sample is a replicate of sample same-numbered, but was located 100-300 feet upstream or downstream from primary sample location.

${ }^{2}$ Estimated based on distances measured to nearby features. 
Table 5. Sample locations and channel-geometry data associated with bed-sediment subsamples, lower Platte River watershed, Nebraska, 2010.

[Reach identifiers correspond to figure 1; Sample site number "1" is most upstream and sample site number " 2 " is most downstream within indicated reach]

\begin{tabular}{|c|c|c|c|c|c|c|c|c|c|c|c|}
\hline $\begin{array}{c}\text { Sample } \\
\text { identifier } \\
\text { code }\end{array}$ & $\begin{array}{c}\text { Reach } \\
\text { identifier }\end{array}$ & $\begin{array}{l}\text { Sampling } \\
\text { site } \\
\text { number }\end{array}$ & $\begin{array}{c}\text { Sample } \\
\text { set } \\
\text { number }\end{array}$ & Date & Time & Latitude & Longitude & $\begin{array}{c}\text { Horizontal } \\
\text { accuracy (feet) }\end{array}$ & $\begin{array}{c}\text { Distance from } \\
\text { left bank } \\
\text { (feet) }\end{array}$ & $\begin{array}{l}\text { Current velocity } \\
\text { (feet per second) }\end{array}$ & $\begin{array}{c}\text { Water depth } \\
\text { (feet) }\end{array}$ \\
\hline \multicolumn{12}{|c|}{ Platte River } \\
\hline 2010001 & UA & 1 & 1 & $7 / 28 / 2010$ & $13: 51$ & $41^{\circ} 20^{\prime} 28.75^{\prime \prime}$ & $97^{\circ} 34^{\prime} 05.67^{\prime \prime}$ & 15 & 468 & 2.37 & 2.3 \\
\hline 2010001 & UA & 1 & 1 & $7 / 28 / 2010$ & $14: 00$ & $41^{\circ} 20^{\prime} 30.38^{\prime \prime}$ & $97^{\circ} 34^{\prime} 09.63 "$ & 12 & 174 & 2.69 & 3.0 \\
\hline 2010001 & UA & 1 & 1 & $7 / 28 / 2010$ & $14: 16$ & $41^{\circ} 20^{\prime} 31.52^{\prime \prime}$ & $97^{\circ} 34^{\prime} 10.99 "$ & 8 & 42 & 2.39 & 2.4 \\
\hline 2010002 & UA & 1 & 2 & $7 / 28 / 2010$ & $12: 37$ & $41^{\circ} 20^{\prime} 29.07$ ' & $97^{\circ} 34^{\prime} 10.25^{\prime \prime}$ & 18 & 303 & 1.59 & .6 \\
\hline 2010002 & UA & 1 & 2 & $7 / 28 / 2010$ & $13: 38$ & $41^{\circ} 20^{\prime} 23.33^{\prime \prime}$ & $97^{\circ} 34^{\prime} 11.09^{\prime \prime}$ & 15 & 1,230 & 1.72 & 1.4 \\
\hline 2010002 & UA & 1 & 2 & $7 / 28 / 2010$ & $14: 30$ & $41^{\circ} 20^{\prime} 30.25^{\prime \prime}$ & $97^{\circ} 34^{\prime} 14.22^{\prime \prime}$ & 18 & 123 & 1.82 & 1.6 \\
\hline 2010008 & UB & 1 & 1 & $7 / 28 / 2010$ & $16: 21$ & $41^{\circ} 23^{\prime} 25.23^{\prime \prime}$ & $97^{\circ} 23^{\prime} 58.86^{\prime \prime}$ & 8 & 15 & 2.17 & 2.7 \\
\hline 2010008 & UB & 1 & 1 & $7 / 28 / 2010$ & $17: 23$ & $41^{\circ} 23^{\prime} 22.00^{\prime \prime}$ & $97^{\circ} 23^{\prime} 53.70^{\prime \prime}$ & 7 & 450 & 2.72 & 3.5 \\
\hline 2010008 & UB & 1 & 1 & $7 / 28 / 2010$ & $17: 40$ & $41^{\circ} 23^{\prime} 19.86^{\prime \prime}$ & $97^{\circ} 23^{\prime} 50.47^{\prime \prime}$ & 12 & 600 & 2.53 & 2.4 \\
\hline 2010009 & UB & 1 & 2 & $7 / 28 / 2010$ & $16: 35$ & $41^{\circ} 23^{\prime} 24.31^{\prime \prime}$ & $97^{\circ} 23^{\prime} 59.54$ " & 15 & 114 & 1.69 & 1.3 \\
\hline 2010009 & UB & 1 & 2 & $7 / 28 / 2010$ & $17: 15$ & $41^{\circ} 23^{\prime} 22.52^{\prime \prime}$ & $97^{\circ} 23^{\prime} 53.70^{\prime \prime}$ & 10 & 420 & .93 & 1.0 \\
\hline 2010009 & UB & 1 & 2 & $7 / 28 / 2010$ & $17: 50$ & $41^{\circ} 23^{\prime} 16.76^{\prime \prime}$ & $97^{\circ} 23^{\prime} 52.29^{\prime \prime}$ & 14 & 984 & 1.49 & .9 \\
\hline 2010015 & $1 \mathrm{~A}$ & 1 & 1 & $7 / 29 / 2010$ & $16: 40$ & $41^{\circ} 22^{\prime} 50.73^{\prime \prime}$ & $97^{\circ} 13^{\prime} 49.46^{\prime \prime}$ & 16 & ${ }^{2} 1,776$ & 3.19 & 2.2 \\
\hline 2010015 & $1 \mathrm{~A}$ & 1 & 1 & $7 / 29 / 2010$ & $17: 25$ & $41^{\circ} 22^{\prime} 57.54^{\prime \prime}$ & $97^{\circ} 13^{\prime} 44.42^{\prime \prime}$ & 15 & 1,077 & 2.96 & 3.1 \\
\hline 2010015 & $1 \mathrm{~A}$ & 1 & 1 & $7 / 29 / 2010$ & $17: 35$ & $41^{\circ} 23^{\prime} 06.58^{\prime \prime}$ & $97^{\circ} 13^{\prime} 54.05^{\prime \prime}$ & 19 & 87 & 2.45 & 2.6 \\
\hline 2010016 & $1 \mathrm{~A}$ & 1 & 2 & $7 / 29 / 2010$ & $16: 48$ & $41^{\circ} 22^{\prime} 52.26^{\prime \prime}$ & $97^{\circ} 13^{\prime} 47.09^{\prime \prime}$ & 15 & ${ }^{2} 1,650$ & 1.28 & .8 \\
\hline 2010016 & $1 \mathrm{~A}$ & 1 & 2 & $7 / 29 / 2010$ & $17: 12$ & $41^{\circ} 22^{\prime} 56.00^{\prime \prime}$ & $97^{\circ} 13^{\prime} 39.38^{\prime \prime}$ & 15 & 1,068 & 1.12 & .5 \\
\hline 2010016 & $1 \mathrm{~A}$ & 1 & 2 & $7 / 29 / 2010$ & $17: 43$ & $41^{\circ} 23^{\prime} 05.07^{\prime \prime}$ & $97^{\circ} 13^{\prime} 54.76^{\prime \prime}$ & 10 & 261 & 1.49 & 1.0 \\
\hline 2010022 & $1 \mathrm{~A}$ & 2 & 1 & $7 / 29 / 2010$ & $14: 30$ & $41^{\circ} 22^{\prime} 58.16^{\prime \prime}$ & $97^{\circ} 09^{\prime} 01.32^{\prime \prime}$ & 18 & 30 & 1.84 & 1.5 \\
\hline 2010022 & $1 \mathrm{~A}$ & 2 & 1 & $7 / 29 / 2010$ & $15: 15$ & $41^{\circ} 22^{\prime} 54.18^{\prime \prime}$ & $97^{\circ} 09^{\prime} 08.06$ " & 15 & 15 & 1.61 & 1.1 \\
\hline 2010022 & $1 \mathrm{~A}$ & 2 & 1 & $7 / 29 / 2010$ & $15: 30$ & $41^{\circ} 22^{\prime} 54.26^{\prime \prime}$ & $97^{\circ} 09^{\prime} 19.52 ”$ & 12 & 30 & .94 & 1.6 \\
\hline 2010023 & $1 \mathrm{~A}$ & 2 & 2 & $7 / 29 / 2010$ & $14: 45$ & $41^{\circ} 23^{\prime} 02.56^{\prime \prime}$ & $97^{\circ} 08^{\prime} 55.57^{\prime \prime}$ & 15 & 120 & 2.58 & 2.7 \\
\hline 2010023 & $1 \mathrm{~A}$ & 2 & 2 & $7 / 29 / 2010$ & $14: 55$ & $41^{\circ} 22^{\prime} 52.60^{\prime \prime}$ & $97^{\circ} 09^{\prime} 04.19^{\prime \prime}$ & 19 & 315 & 2.45 & 3.3 \\
\hline 2010023 & $1 \mathrm{~A}$ & 2 & 2 & $7 / 29 / 2010$ & $15: 03$ & $41^{\circ} 22^{\prime} 51.07^{\prime \prime}$ & $97^{\circ} 09^{\prime} 11.60 "$ & 15 & 690 & 2.26 & 2.3 \\
\hline 2010029 & 1B & 1 & 1 & $7 / 30 / 2010$ & $10: 45$ & $41^{\circ} 26^{\prime} 39.97^{\prime \prime}$ & $96^{\circ} 57^{\prime} 39.72^{\prime \prime}$ & 12 & 354 & 1.11 & 1.8 \\
\hline 2010029 & 1B & 1 & 1 & $7 / 30 / 2010$ & $11: 15$ & $41^{\circ} 26^{\prime} 37.30^{\prime \prime}$ & $96^{\circ} 57^{\prime} 38.15^{\prime \prime}$ & 12 & 648 & 1.67 & 1.4 \\
\hline 2010029 & 1B & 1 & 1 & $7 / 30 / 2010$ & $12: 46$ & $41^{\circ} 26^{\prime} 30.52^{\prime \prime}$ & $96^{\circ} 57^{\prime} 35.79^{\prime \prime}$ & 18 & 1,110 & 1.47 & .8 \\
\hline 2010030 & $1 \mathrm{~B}$ & 1 & 2 & $7 / 30 / 2010$ & $11: 00$ & $41^{\circ} 26^{\prime} 40.80^{\prime \prime}$ & $96^{\circ} 57^{\prime} 39.10^{\prime \prime}$ & 13 & 297 & 2.15 & 2.4 \\
\hline 2010030 & $1 \mathrm{~B}$ & 1 & 2 & $7 / 30 / 2010$ & $11: 45$ & $41^{\circ} 26^{\prime} 43.38^{\prime \prime}$ & $96^{\circ} 57^{\prime} 30.50^{\prime \prime}$ & 12 & 198 & 2.22 & 2.5 \\
\hline 2010030 & $1 \mathrm{~B}$ & 1 & 2 & $7 / 30 / 2010$ & $12: 37$ & $41^{\circ} 26^{\prime} 30.05^{\prime \prime}$ & $96^{\circ} 57^{\prime} 34.52^{\prime \prime}$ & 20 & 1,557 & 2.67 & 2.6 \\
\hline 2010036 & $1 \mathrm{~B}$ & 2 & 1 & $7 / 30 / 2010$ & $14: 00$ & $41^{\circ} 27^{\prime} 19.32^{\prime \prime}$ & $96^{\circ} 52^{\prime} 31.61^{\prime \prime}$ & 15 & 1,464 & 2.24 & 2.9 \\
\hline 2010037 & $1 \mathrm{~B}$ & 2 & 1 & $7 / 30 / 2010$ & $14: 50$ & $41^{\circ} 27^{\prime} 26.08^{\prime \prime}$ & $96^{\circ} 52^{\prime} 30.57^{\prime \prime}$ & 14 & 192 & 2.96 & 2.4 \\
\hline
\end{tabular}


[Reach identifiers correspond to figure 1; Sample site number "1" is most upstream and sample site number " 2 " is most downstream within indicated reach]

\begin{tabular}{|c|c|c|c|c|c|c|c|c|c|c|c|}
\hline $\begin{array}{c}\text { Sample } \\
\text { identifier } \\
\text { code }\end{array}$ & $\begin{array}{l}\text { Reach } \\
\text { identifier }\end{array}$ & $\begin{array}{l}\text { Sampling } \\
\text { site } \\
\text { number }\end{array}$ & $\begin{array}{c}\text { Sample } \\
\text { set } \\
\text { number }\end{array}$ & Date & Time & Latitude & Longitude & $\begin{array}{c}\text { Horizontal } \\
\text { accuracy (feet) }\end{array}$ & $\begin{array}{c}\text { Distance from } \\
\text { left bank } \\
\text { (feet) }\end{array}$ & $\begin{array}{l}\text { Current velocity } \\
\text { (feet per second) }\end{array}$ & $\begin{array}{l}\text { Water depth } \\
\text { (feet) }\end{array}$ \\
\hline \multicolumn{12}{|c|}{ Platte River-Continued } \\
\hline 2010038 & $1 \mathrm{~B}$ & 2 & 1 & $7 / 30 / 2010$ & $16: 10$ & $41^{\circ} 27^{\prime} 33.63^{\prime \prime}$ & $96^{\circ} 52^{\prime} 21.62^{\prime \prime}$ & 16 & 48 & 2.07 & 1.9 \\
\hline 2010039 & $1 \mathrm{~B}$ & 2 & 2 & $7 / 30 / 2010$ & $14: 40$ & $41^{\circ} 27^{\prime} 21.97^{\prime \prime}$ & $96^{\circ} 52^{\prime} 26.80^{\prime \prime}$ & 13 & 1,311 & .82 & .6 \\
\hline 2010039 & $1 \mathrm{~B}$ & 2 & 2 & $7 / 30 / 2010$ & $15: 06$ & $41^{\circ} 27^{\prime} 27.81^{\prime \prime}$ & $96^{\circ} 52^{\prime} 28.58^{\prime \prime}$ & 15 & 768 & 1.35 & 1.6 \\
\hline 2010039 & $1 \mathrm{~B}$ & 2 & 2 & $7 / 30 / 2010$ & 16:02 & $41^{\circ} 27^{\prime} 31.97^{\prime \prime}$ & $96^{\circ} 52^{\prime} 25.55^{\prime \prime}$ & 6 & 279 & 1.66 & .7 \\
\hline 2010045 & $1 \mathrm{~B}$ & 12 & 1 & $7 / 30 / 2010$ & $14: 05$ & $41^{\circ} 27^{\prime} 19.54^{\prime \prime}$ & $96^{\circ} 52^{\prime} 27.82^{\prime}$ & 20 & 1,644 & 2.48 & 3.0 \\
\hline 2010048 & $1 \mathrm{C}$ & 1 & 1 & $7 / 27 / 2010$ & $11: 54$ & $41^{\circ} 25^{\prime} 52.47^{\prime}$ & $96^{\circ} 40^{\prime} 15.92^{\prime \prime}$ & 16 & 123 & 3.17 & 2.7 \\
\hline 2010048 & $1 \mathrm{C}$ & 1 & 1 & $7 / 27 / 2010$ & $12: 17$ & $41^{\circ} 25^{\prime} 50.55^{\prime \prime}$ & $96^{\circ} 40^{\prime} 15.04 "$ & 20 & 315 & 2.13 & 3.9 \\
\hline 2010048 & $1 \mathrm{C}$ & 1 & 1 & $7 / 27 / 2010$ & $13: 45$ & $41^{\circ} 25^{\prime} 43.76^{\prime \prime}$ & $96^{\circ} 40^{\prime} 12.85^{\prime \prime}$ & 14 & 1,110 & 2.17 & 2.7 \\
\hline 2010049 & $1 \mathrm{C}$ & 1 & 2 & $7 / 27 / 2010$ & $12: 30$ & $41^{\circ} 25^{\prime} 49.01^{\prime \prime}$ & $96^{\circ} 40^{\prime} 15.25^{\prime \prime}$ & 16 & 486 & 1.49 & 1.1 \\
\hline 2010049 & $1 \mathrm{C}$ & 1 & 2 & $7 / 27 / 2010$ & $13: 30$ & $41^{\circ} 25^{\prime} 45.12^{\prime \prime}$ & $96^{\circ} 40^{\prime} 14.76^{\prime \prime}$ & 17 & 891 & 1.75 & .8 \\
\hline 2010049 & $1 \mathrm{C}$ & 1 & 2 & $7 / 27 / 2010$ & $14: 00$ & $41^{\circ} 25^{\prime} 40.59^{\prime \prime}$ & $96^{\circ} 40^{\prime} 12.53^{\prime \prime}$ & 21 & 1,479 & .43 & .5 \\
\hline 2010056 & $1 \mathrm{C}$ & 2 & 1 & $7 / 27 / 2010$ & $15: 20$ & $41^{\circ} 26^{\prime} 14.21^{\prime \prime}$ & $96^{\circ} 35^{\prime} 15.30^{\prime \prime}$ & 15 & 162 & 3.14 & 3.0 \\
\hline 2010056 & $1 \mathrm{C}$ & 2 & 1 & $7 / 27 / 2010$ & $17: 00$ & $41^{\circ} 26^{\prime} 03.43^{\prime \prime}$ & $96^{\circ} 35^{\prime} 24.15^{\prime \prime}$ & 18 & 1,380 & 3.23 & 2.8 \\
\hline 2010056 & $1 \mathrm{C}$ & 2 & 1 & $7 / 27 / 2010$ & $17: 19$ & $41^{\circ} 26^{\prime} 03.68^{\prime \prime}$ & $96^{\circ} 35^{\prime} 12.33^{\prime \prime}$ & 20 & 1,233 & 2.13 & 2.6 \\
\hline 2010057 & $1 \mathrm{C}$ & 2 & 2 & $7 / 27 / 2010$ & $15: 35$ & $41^{\circ} 26^{\prime} 11.38^{\prime \prime}$ & $96^{\circ} 35^{\prime} 17.56^{\prime \prime}$ & 17 & 474 & 1.59 & .8 \\
\hline 2010057 & $1 \mathrm{C}$ & 2 & 2 & $7 / 27 / 2010$ & $15: 40$ & $41^{\circ} 26^{\prime} 09.16^{\prime \prime}$ & $96^{\circ} 35^{\prime} 15.16^{\prime \prime}$ & 25 & 678 & .58 & 1.1 \\
\hline 2010057 & $1 \mathrm{C}$ & 2 & 2 & $7 / 27 / 2010$ & $17: 09$ & $41^{\circ} 26^{\prime} 05.27^{\prime \prime}$ & $96^{\circ} 35^{\prime} 26.49^{\prime \prime}$ & 8 & 918 & 1.33 & .8 \\
\hline 2010063 & $1 \mathrm{D}$ & 1 & 1 & $7 / 26 / 2010$ & $10: 55$ & $41^{\circ} 22^{\prime} 05.17^{\prime \prime}$ & $96^{\circ} 25^{\prime} 51.89^{\prime \prime}$ & 10 & 811 & 2.40 & 2.0 \\
\hline 2010063 & $1 \mathrm{D}$ & 1 & 1 & $7 / 26 / 2010$ & $11: 04$ & $41^{\circ} 22^{\prime} 08.26^{\prime \prime}$ & $96^{\circ} 25^{\prime} 52.23^{\prime \prime}$ & 8 & 570 & 2.31 & 3.2 \\
\hline 2010063 & $1 \mathrm{D}$ & 1 & 1 & $7 / 26 / 2010$ & $11: 20$ & $41^{\circ} 22^{\prime} 10.44^{\prime \prime}$ & $96^{\circ} 25^{\prime} 51.76^{\prime \prime}$ & 7 & 194 & 2.74 & 3.2 \\
\hline 2010064 & $1 \mathrm{D}$ & 1 & 2 & $7 / 26 / 2010$ & $11: 40$ & $41^{\circ} 22^{\prime} 11.43^{\prime \prime}$ & $96^{\circ} 25^{\prime} 51.51^{\prime \prime}$ & 10 & 90 & 1.77 & 1.1 \\
\hline 2010064 & $1 \mathrm{D}$ & 1 & 2 & $7 / 26 / 2010$ & $12: 40$ & $41^{\circ} 22^{\prime} 07.23^{\prime \prime}$ & $96^{\circ} 25^{\prime} 53.42^{\prime \prime}$ & 11 & 360 & 1.94 & 1.3 \\
\hline 2010064 & $1 \mathrm{D}$ & 1 & 2 & $7 / 26 / 2010$ & $13: 30$ & $41^{\circ} 22^{\prime} 02.52^{\prime \prime}$ & $96^{\circ} 25^{\prime} 51.15^{\prime \prime}$ & 17 & 903 & 1.25 & 1.3 \\
\hline 2010070 & $1 \mathrm{D}$ & 2 & 1 & $8 / 10 / 2010$ & $12: 01$ & $41^{\circ} 19^{\prime} 19.21^{\prime \prime}$ & $96^{\circ} 24^{\prime} 17.29^{\prime \prime}$ & 17 & 84 & 2.51 & 2.8 \\
\hline 2010070 & $1 \mathrm{D}$ & 2 & 1 & $8 / 10 / 2010$ & $12: 19$ & $41^{\circ} 19^{\prime} 27.54^{\prime \prime}$ & $96^{\circ} 24^{\prime} 29.88^{\prime \prime}$ & 22 & 1,065 & 2.14 & 2.9 \\
\hline 2010070 & $1 \mathrm{D}$ & 2 & 1 & $8 / 10 / 2010$ & $13: 20$ & $41^{\circ} 19^{\prime} 25.15^{\prime \prime}$ & $96^{\circ} 24^{\prime} 36.40^{\prime \prime}$ & 18 & 171 & 1.98 & 2.4 \\
\hline 2010071 & $1 \mathrm{D}$ & 2 & 2 & $8 / 10 / 2010$ & $10: 25$ & $41^{\circ} 19^{\prime} 21.87^{\prime \prime}$ & $96^{\circ} 24^{\prime} 20.79^{\prime \prime}$ & 16 & 357 & 1.93 & 1.0 \\
\hline 2010071 & $1 \mathrm{D}$ & 2 & 2 & $8 / 10 / 2010$ & $12: 38$ & $41^{\circ} 19^{\prime} 24.69^{\prime \prime}$ & $96^{\circ} 24^{\prime} 31.06^{\prime \prime}$ & 15 & 1,146 & 1.70 & 1.2 \\
\hline 2010071 & $1 \mathrm{D}$ & 2 & 2 & $8 / 10 / 2010$ & $13: 09$ & $41^{\circ} 19^{\prime} 28.47^{\prime \prime}$ & $96^{\circ} 24^{\prime} 36.67^{\prime \prime}$ & 14 & 1,500 & 1.85 & 1.3 \\
\hline 2010077 & $1 \mathrm{E}$ & 1 & 1 & $8 / 10 / 2010$ & $15: 24$ & $41^{\circ} 12^{\prime} 56.50^{\prime \prime}$ & $96^{\circ} 21^{\prime} 33.17^{\prime \prime}$ & 15 & 1,098 & 2.44 & 2.4 \\
\hline 2010077 & $1 \mathrm{E}$ & 1 & 1 & $8 / 10 / 2010$ & $15: 36$ & $41^{\circ} 12^{\prime} 49.60^{\prime \prime}$ & $96^{\circ} 21^{\prime} 37.24 "$ & 20 & 1,644 & 3.29 & 2.4 \\
\hline
\end{tabular}


Table 5. Sample locations and channel-geometry data associated with bed-sediment subsamples, lower Platte River watershed, Nebraska, 2010.-Continued

[Reach identifiers correspond to figure 1; Sample site number "1" is most upstream and sample site number "2" is most downstream within indicated reach]

\begin{tabular}{|c|c|c|c|c|c|c|c|c|c|c|c|}
\hline $\begin{array}{l}\text { Sample } \\
\text { identifier } \\
\text { code }\end{array}$ & $\begin{array}{c}\text { Reach } \\
\text { identifier }\end{array}$ & $\begin{array}{l}\text { Sampling } \\
\text { site } \\
\text { number }\end{array}$ & $\begin{array}{c}\text { Sample } \\
\text { set } \\
\text { number }\end{array}$ & Date & Time & Latitude & Longitude & $\begin{array}{c}\text { Horizontal } \\
\text { accuracy (feet) }\end{array}$ & $\begin{array}{l}\text { Distance from } \\
\text { left bank } \\
\text { (feet) }\end{array}$ & $\begin{array}{l}\text { Current velocity } \\
\text { (feet per second) }\end{array}$ & $\begin{array}{l}\text { Water depth } \\
\text { (feet) }\end{array}$ \\
\hline \multicolumn{12}{|c|}{ Platte River-Continued } \\
\hline 2010077 & $1 \mathrm{E}$ & 1 & 1 & $8 / 10 / 2010$ & $16: 18$ & $41^{\circ} 13^{\prime} 04.51^{\prime \prime}$ & $96^{\circ} 21^{\prime} 24.50^{\prime \prime}$ & 18 & 45 & 2.56 & 2.2 \\
\hline 2010078 & $1 \mathrm{E}$ & 1 & 2 & $8 / 10 / 2010$ & $15: 16$ & $41^{\circ} 12^{\prime} 56.36^{\prime \prime}$ & $96^{\circ} 21^{\prime} 32.47^{\prime \prime}$ & 14 & 1,041 & 1.85 & .9 \\
\hline 2010078 & $1 \mathrm{E}$ & 1 & 2 & $8 / 10 / 2010$ & $16: 05$ & $41^{\circ} 13^{\prime} 08.09^{\prime \prime}$ & $96^{\circ} 21^{\prime} 43.64 ”$ & 14 & 1,176 & 1.23 & 1.3 \\
\hline 2010078 & $1 \mathrm{E}$ & 1 & 2 & $8 / 10 / 2010$ & $16: 25$ & $41^{\circ} 13^{\prime} 03.05^{\prime \prime}$ & $96^{\circ} 21^{\prime} 24.74^{\prime \prime}$ & 14 & 141 & 1.86 & 1.0 \\
\hline 2010084 & $1 \mathrm{E}$ & 2 & 1 & $8 / 11 / 2010$ & $11: 20$ & $41^{\circ} 11^{\prime} 15.84 "$ & $96^{\circ} 19^{\prime} 39.85^{\prime \prime}$ & 15 & 1,185 & 2.42 & 2.8 \\
\hline 2010084 & $1 \mathrm{E}$ & 2 & 1 & $8 / 11 / 2010$ & $11: 29$ & $41^{\circ} 11^{\prime} 14.51^{\prime \prime}$ & $96^{\circ} 19^{\prime} 34.89^{\prime \prime}$ & 15 & 1,029 & 2.39 & 2.5 \\
\hline 2010084 & $1 \mathrm{E}$ & 2 & 1 & $8 / 11 / 2010$ & $11: 39$ & $41^{\circ} 11^{\prime} 12.23 "$ & $96^{\circ} 19^{\prime} 26.81^{\prime \prime}$ & 20 & 479 & 2.79 & 2.0 \\
\hline 2010085 & $1 \mathrm{E}$ & 2 & 2 & $8 / 11 / 2010$ & $11: 50$ & $41^{\circ} 11^{\prime} 07.76^{\prime \prime}$ & $96^{\circ} 19^{\prime} 27.22^{\prime \prime}$ & 15 & 585 & 1.45 & .9 \\
\hline 2010085 & $1 \mathrm{E}$ & 2 & 2 & $8 / 11 / 2010$ & $12: 26$ & $41^{\circ} 11^{\prime} 14.83^{\prime \prime}$ & $96^{\circ} 19^{\prime} 25.48^{\prime \prime}$ & 20 & 330 & 1.60 & 1.1 \\
\hline 2010085 & $1 \mathrm{E}$ & 2 & 2 & $8 / 11 / 2010$ & $12: 35$ & $41^{\circ} 11^{\prime} 16.07 "$ & $96^{\circ} 19^{\prime} 37.91 ”$ & 24 & 1,095 & 1.75 & .8 \\
\hline 2010092 & $2 \mathrm{~A}$ & 1 & 1 & $8 / 11 / 2010$ & $14: 48$ & $41^{\circ} 06^{\prime} 12.16^{\prime \prime}$ & $96^{\circ} 19^{\prime} 51.00^{\prime \prime}$ & 17 & 1,356 & 2.00 & 2.4 \\
\hline 2010092 & $2 \mathrm{~A}$ & 1 & 1 & $8 / 11 / 2010$ & $15: 00$ & $41^{\circ} 06^{\prime} 04.62^{\prime \prime}$ & $96^{\circ} 19^{\prime} 58.58^{\prime \prime}$ & 14 & ${ }^{2} 1,146$ & 2.43 & 2.9 \\
\hline 2010092 & $2 \mathrm{~A}$ & 1 & 1 & $8 / 11 / 2010$ & $15: 07$ & $41^{\circ} 05^{\prime} 49.92^{\prime \prime}$ & $96^{\circ} 20^{\prime} 10.15^{\prime \prime}$ & 16 & 840 & 2.04 & 2.2 \\
\hline 2010093 & $2 \mathrm{~A}$ & 1 & 2 & $8 / 11 / 2010$ & $15: 20$ & $41^{\circ} 06^{\prime} 01.67^{\prime \prime}$ & $96^{\circ} 20^{\prime} 00.92 ”$ & 20 & 1,155 & .94 & 1.0 \\
\hline 2010093 & $2 \mathrm{~A}$ & 1 & 2 & $8 / 11 / 2010$ & $15: 50$ & $41^{\circ} 05^{\prime} 54.14 "$ & $96^{\circ} 20^{\prime} 05.95^{\prime \prime}$ & 18 & 777 & 1.50 & 1.3 \\
\hline 2010093 & $2 \mathrm{~A}$ & 1 & 2 & $8 / 11 / 2010$ & $16: 20$ & $41^{\circ} 05^{\prime} 49.40^{\prime \prime}$ & $96^{\circ} 20^{\prime} 09.51^{\prime \prime}$ & 17 & 1,797 & 1.75 & 1.3 \\
\hline 2010102 & $2 \mathrm{~B}$ & 1 & 1 & $8 / 11 / 2010$ & $17: 18$ & $41^{\circ} 04^{\prime} 34.05^{\prime \prime}$ & $96^{\circ} 20^{\prime} 00.87^{\prime \prime}$ & 15 & 300 & 2.92 & 2.6 \\
\hline 2010102 & $2 \mathrm{~B}$ & 1 & 1 & $8 / 11 / 2010$ & $17: 30$ & $41^{\circ} 04^{\prime} 19.95^{\prime \prime}$ & $96^{\circ} 19^{\prime} 53.59^{\prime \prime}$ & 15 & 141 & 2.27 & 2.5 \\
\hline 2010102 & $2 \mathrm{~B}$ & 1 & 1 & $8 / 11 / 2010$ & $17: 40$ & $41^{\circ} 04^{\prime} 24.98^{\prime \prime}$ & $96^{\circ} 20^{\prime} 06.69^{\prime \prime}$ & 18 & 720 & 2.81 & 2.6 \\
\hline 2010099 & $2 \mathrm{~B}$ & 1 & 2 & $8 / 11 / 2010$ & $17: 48$ & $41^{\circ} 04^{\prime} 25.02^{\prime \prime}$ & $96^{\circ} 20^{\prime} 03.80^{\prime \prime}$ & 9 & 720 & 1.66 & 1.3 \\
\hline 2010100 & $2 \mathrm{~B}$ & 1 & 2 & $8 / 11 / 2010$ & $18: 20$ & $41^{\circ} 04^{\prime} 36.51^{\prime \prime}$ & $96^{\circ} 20^{\prime} 22.77^{\prime \prime}$ & 19 & ${ }^{2} 1,653$ & 1.83 & 1.5 \\
\hline 2010101 & $2 \mathrm{~B}$ & 1 & 2 & $8 / 11 / 2010$ & $19: 00$ & $41^{\circ} 04^{\prime} 34.05^{\prime \prime}$ & $96^{\circ} 20^{\prime} 02.77^{\prime \prime}$ & 18 & 450 & 1.12 & 1.7 \\
\hline 2010108 & $2 \mathrm{~B}$ & ${ }^{1} 1$ & 1 & $8 / 11 / 2010$ & $18: 00$ & $41^{\circ} 04^{\prime} 26.42^{\prime \prime}$ & $96^{\circ} 20^{\prime} 07.06^{\prime \prime}$ & 15 & 939 & 1.47 & .9 \\
\hline 2010112 & $3 \mathrm{~A}$ & 1 & 1 & $8 / 12 / 2010$ & $12: 35$ & $41^{\circ} 01^{\prime} 02.32^{\prime \prime}$ & $96^{\circ} 14^{\prime} 46.51^{\prime \prime}$ & 15 & 258 & 2.67 & 2.7 \\
\hline 2010112 & $3 \mathrm{~A}$ & 1 & 1 & $8 / 12 / 2010$ & $12: 50$ & $41^{\circ} 00^{\prime} 46.47^{\prime \prime}$ & $96^{\circ} 14^{\prime} 34.17^{\prime \prime}$ & 11 & 639 & 2.90 & 2.6 \\
\hline 2010112 & $3 \mathrm{~A}$ & 1 & 1 & $8 / 12 / 2010$ & $13: 25$ & $41^{\circ} 00^{\prime} 48.37^{\prime \prime}$ & $96^{\circ} 14^{\prime} 55.54 ”$ & 17 & 1,809 & 2.90 & 2.2 \\
\hline 2010113 & $3 \mathrm{~A}$ & 1 & 2 & $8 / 12 / 2010$ & $12: 15$ & $41^{\circ} 01^{\prime} 01.72^{\prime \prime}$ & $96^{\circ} 14^{\prime} 47.03^{\prime \prime}$ & 15 & 324 & 1.30 & 1.1 \\
\hline 2010113 & $3 \mathrm{~A}$ & 1 & 2 & $8 / 12 / 2010$ & $13: 15$ & $41^{\circ} 00^{\prime} 50.02^{\prime \prime}$ & $96^{\circ} 14^{\prime} 39.14^{\prime \prime}$ & 13 & 732 & 1.67 & 1.4 \\
\hline 2010113 & $3 \mathrm{~A}$ & 1 & 2 & $8 / 12 / 2010$ & $13: 50$ & $41^{\circ} 00^{\prime} 55.51^{\prime \prime}$ & $96^{\circ} 15^{\prime} 07.90^{\prime \prime}$ & 14 & 1,821 & 1.35 & 1.7 \\
\hline 2010119 & $3 \mathrm{~B}$ & 1 & 1 & $8 / 12 / 2010$ & $15: 40$ & $41^{\circ} 03^{\prime} 13.30^{\prime \prime}$ & $96^{\circ} 05^{\prime} 56.64^{\prime \prime}$ & 14 & 345 & 2.34 & 2.1 \\
\hline 2010120 & $3 \mathrm{~B}$ & 1 & 1 & $8 / 12 / 2010$ & $16: 35$ & $41^{\circ} 03^{\prime} 07.41^{\prime \prime}$ & $96^{\circ} 05^{\prime} 41.30^{\prime \prime}$ & 18 & 1,134 & 2.91 & 2.7 \\
\hline 2010121 & $3 \mathrm{~B}$ & 1 & 1 & $8 / 12 / 2010$ & $16: 48$ & $41^{\circ} 03^{\prime} 18.16^{\prime \prime}$ & $96^{\circ} 05^{\prime} 14.98^{\prime \prime}$ & 16 & 666 & 2.25 & 2.5 \\
\hline
\end{tabular}


Table 5. Sample locations and channel-geometry data associated with bed-sediment subsamples, lower Platte River watershed, Nebraska, 2010.—Continued

[Reach identifiers correspond to figure 1; Sample site number "1" is most upstream and sample site number " 2 " is most downstream within indicated reach]

\begin{tabular}{|c|c|c|c|c|c|c|c|c|c|c|c|}
\hline $\begin{array}{c}\text { Sample } \\
\text { identifier } \\
\text { code }\end{array}$ & $\begin{array}{c}\text { Reach } \\
\text { identifier }\end{array}$ & $\begin{array}{l}\text { Sampling } \\
\text { site } \\
\text { number }\end{array}$ & $\begin{array}{c}\text { Sample } \\
\text { set } \\
\text { number }\end{array}$ & Date & Time & Latitude & Longitude & $\begin{array}{c}\text { Horizontal } \\
\text { accuracy (feet) }\end{array}$ & $\begin{array}{l}\text { Distance from } \\
\text { left bank } \\
\text { (feet) }\end{array}$ & $\begin{array}{l}\text { Current velocity } \\
\text { (feet per second) }\end{array}$ & $\begin{array}{c}\text { Water depth } \\
\text { (feet) }\end{array}$ \\
\hline \multicolumn{12}{|c|}{ Platte River-Continued } \\
\hline 2010122 & $3 \mathrm{~B}$ & 1 & 2 & $8 / 12 / 2010$ & $16: 00$ & $41^{\circ} 03^{\prime} 04.93 "$ & $96^{\circ} 05^{\prime} 52.05^{\prime \prime}$ & 16 & 1,263 & 1.54 & 0.6 \\
\hline 2010122 & $3 \mathrm{~B}$ & 1 & 2 & $8 / 12 / 2010$ & $16: 55$ & $41^{\circ} 03^{\prime} 17.52^{\prime \prime}$ & $96^{\circ} 05^{\prime} 11.33^{\prime \prime}$ & 17 & 780 & 1.09 & .8 \\
\hline 2010122 & $3 \mathrm{~B}$ & 1 & 2 & $8 / 12 / 2010$ & $17: 25$ & $41^{\circ} 03^{\prime} 17.00^{\prime \prime}$ & $96^{\circ} 05^{\prime} 31.11^{\prime \prime}$ & 23 & 471 & 1.39 & .9 \\
\hline 2010128 & $3 \mathrm{~B}$ & ${ }^{1} 1$ & 1 & $8 / 12 / 2010$ & $15: 50$ & $41^{\circ} 03^{\prime} 15.28^{\prime \prime}$ & $96^{\circ} 05^{\prime} 42.55^{\prime \prime}$ & 16 & 345 & 2.44 & 2.6 \\
\hline 2010132 & 3B & 2 & 1 & $8 / 13 / 2010$ & $11: 00$ & $41^{\circ} 03^{\prime} 30.35^{\prime \prime}$ & $95^{\circ} 57^{\prime} 21.86^{\prime \prime}$ & 17 & 1,305 & 1.57 & 1.2 \\
\hline 2010132 & $3 \mathrm{~B}$ & 2 & 1 & $8 / 13 / 2010$ & $11: 31$ & $41^{\circ} 03^{\prime} 36.28^{\prime \prime}$ & $95^{\circ} 57^{\prime} 26.27^{\prime \prime}$ & 19 & 876 & 1.21 & .9 \\
\hline 2010132 & $3 \mathrm{~B}$ & 2 & 1 & $8 / 13 / 2010$ & $12: 15$ & $41^{\circ} 03^{\prime} 35.24^{\prime \prime}$ & $95^{\circ} 57^{\prime} 58.61 ”$ & 15 & 138 & 1.75 & 1.3 \\
\hline 2010133 & $3 \mathrm{~B}$ & 2 & 2 & $8 / 13 / 2010$ & $11: 10$ & $41^{\circ} 03^{\prime} 33.16^{\prime \prime}$ & $95^{\circ} 57^{\prime} 27.51^{\prime \prime}$ & 15 & 1,350 & 2.84 & 2.1 \\
\hline 2010133 & $3 \mathrm{~B}$ & 2 & 2 & $8 / 13 / 2010$ & $11: 55$ & $41^{\circ} 03^{\prime} 40.17^{\prime \prime}$ & $95^{\circ} 57^{\prime} 19.93 "$ & 15 & 210 & 2.14 & 2.4 \\
\hline 2010133 & 3B & 2 & 2 & $8 / 13 / 2010$ & $12: 10$ & $41^{\circ} 03^{\prime} 41.20^{\prime \prime}$ & $95^{\circ} 57^{\prime} 44.99^{\prime \prime}$ & 20 & 357 & 2.64 & 2.8 \\
\hline \multicolumn{12}{|c|}{ Loup River } \\
\hline 2010139 & A & 1 & 1 & $7 / 23 / 2010$ & $12: 30$ & $41^{\circ} 20^{\prime} 15.17 \prime$ & $97^{\circ} 59^{\prime} 34.31^{\prime \prime}$ & 11 & 25 & 2.09 & 1.5 \\
\hline 2010141 & B & 1 & 1 & $7 / 29 / 2010$ & $8: 38$ & $41^{\circ} 27^{\prime} 27.17^{\prime \prime}$ & $97^{\circ} 36^{\prime} 06.83^{\prime \prime}$ & 20 & 351 & 1.88 & 1.6 \\
\hline 2010144 & $\mathrm{C}$ & 1 & 1 & $7 / 29 / 2010$ & $11: 05$ & $41^{\circ} 24^{\prime} 01.32^{\prime \prime}$ & $97^{\circ} 19^{\prime} 38.65^{\prime \prime}$ & 16 & 42 & 2.17 & 3.4 \\
\hline \multicolumn{12}{|c|}{ Shell Creek } \\
\hline 2010146 & A & 1 & 1 & $8 / 20 / 2010$ & $11: 38$ & $41^{\circ} 31^{\prime} 34.00^{\prime \prime}$ & $97^{\circ} 16^{\prime} 52.75^{\prime \prime}$ & 25 & 14 & 0.80 & 3.3 \\
\hline 2010148 & B & 1 & 1 & $8 / 20 / 2010$ & $12: 30$ & $41^{\circ} 31^{\prime} 08.49^{\prime \prime}$ & $97^{\circ} 13^{\prime} 58.95^{\prime \prime}$ & 20 & 13 & .50 & 3.1 \\
\hline 2010150 & $\mathrm{C}$ & 1 & 1 & $8 / 20 / 2010$ & 10:05 & $41^{\circ} 27^{\prime} 13.01^{\prime \prime}$ & $97^{\circ} 00^{\prime} 06.38^{\prime \prime}$ & 16 & 20 & 1.01 & 1.2 \\
\hline \multicolumn{12}{|c|}{ Elkhorn River } \\
\hline 2010152 & A & 1 & 1 & $8 / 19 / 2010$ & $15: 45$ & $41^{\circ} 27^{\prime} 13.78^{\prime \prime}$ & $96^{\circ} 22^{\prime} 11.65^{\prime \prime}$ & 18 & 90 & 1.20 & 4.0 \\
\hline 2010154 & B & 1 & 1 & $8 / 19 / 2010$ & $13: 20$ & $41^{\circ} 20^{\prime} 59.59^{\prime \prime}$ & $96^{\circ} 17^{\prime} 30.89^{\prime \prime}$ & 20 & 135 & 2.64 & 2.2 \\
\hline 2010156 & $\mathrm{C}$ & 1 & 1 & $8 / 11 / 2010$ & 14:04 & $41^{\circ} 08^{\prime} 04.48^{\prime \prime}$ & $96^{\circ} 18^{\prime} 39.71 ”$ & 14 & 204 & 1.88 & 1.7 \\
\hline \multicolumn{12}{|c|}{ Salt Creek } \\
\hline 2010158 & A & 1 & 1 & $8 / 19 / 2010$ & $10: 00$ & $41^{\circ} 01^{\prime} 43.52^{\prime \prime}$ & $96^{\circ} 23^{\prime} 16.64 "$ & 18 & 81 & 0.51 & $4.6,3.0$ \\
\hline 2010160 & B & 1 & 1 & $8 / 19 / 2010$ & $11: 25$ & $41^{\circ} 02^{\prime} 05.40^{\prime \prime}$ & $96^{\circ} 22^{\prime} 04.02^{\prime \prime}$ & 22 & 81 & .45 & 3.2 \\
\hline 2010162 & $\mathrm{C}$ & 1 & 1 & $8 / 12 / 2010$ & $11: 05$ & $41^{\circ} 02^{\prime} 26.75^{\prime \prime}$ & $96^{\circ} 19^{\prime} 26.29^{\prime \prime}$ & 21 & 135 & ${ }^{3} .25$ & 8.0 \\
\hline
\end{tabular}

'Sample is a replicate of sample same-numbered, but was located 100-300 feet upstream or downstream from primary sample location.

${ }^{2}$ Estimated based on distances measured to nearby features.

${ }^{3}$ Estimated based on visual observation. 


\section{References Cited}

Ayres Associates and Olsson Associates, 2009, Channel geomorphology and in-channel vegetation monitoring of the central Platte River-Year 1 (2009): Fort Collins, Colo., Ayres Associates, $47 \mathrm{p}$.

Bridge, J.S., 2003, Rivers and flood plains-Forms, processes, and sedimentary record: Oxford, England, Blackwell Publishing, $491 \mathrm{p}$.

Brown, M.B., and Jorgensen, J.G., 2008, 2008 Interior least tern and piping plover monitoring, research, management, and outreach report for the lower Platte River, Nebraska: Joint Report of the Tern and Plover Conservation Partnership and the Nebraska Game and Parks Commission, 60 p.

Bull, L.J., and Kirkby, M.J., 1997, Gully processes and modeling: Progress in Physical Geography, v. 21, p. 354-374.

Davis, B.E., 2005, A Guide to the proper selection and use of federally approved sediment and water-quality samplers: U.S. Geological Survey Open-File Report 2005-1087, 20 p.

Edwards, T.K., and Glysson, G.D., 1999, Field methods for measurement of fluvial sediment: U.S. Geological Survey Techniques of Water-Resource Investigations, book 3 , chap. C2, $87 \mathrm{p}$.

Eschner, T.R., Hadley, R.F., and Crowley, K.D., 1983, Hydrologic and morphologic changes in channels of the Platte River basin in Colorado, Wyoming, and Nebraska-A historical perspective: U.S. Geological Survey Professional Paper 1277-A, 39 p.

Evans, D.J., Gibson, C.E., and Rossell, R.S., 2006, Sediment loads and sources in heavily modified Irish catchments-A move towards informed management strategies: Geomorphology, v. 79, p. 93-113.

Farm Service Agency, 2007, USDA-FSA-APFO NAIP county mosaic: Salt Lake City, Utah, U.S. Department of Agriculture, Farm Service Agency, Aerial Photography Field Office, aerial photograph mosaic, accessed August 2010 at http://datagateway.nrcs.usda.gov, scale 1:40,000.

Ginting, Daniel, Zelt, R.B., and Linard, J.I., 2008, Temporal differences in the hydrologic regime of the lower Platte River, Nebraska, 1895-2006: U.S. Geological Survey Scientific Investigations Report 2007-5267, 43 p.

Ginting, Daniel, and Zelt, R.B., 2008, Temporal differences in flow depth and velocity distributions and hydraulic microhabitats near bridges of the lower Platte River, Nebraska, 1934-2006: U.S. Geological Survey Scientific Investigations Report 2008-5054, 98 p.
Guy, H.P., 1969, Laboratory theory and methods for sediment analysis: U.S. Geological Survey Techniques of WaterResources Investigations, book 5, chap. C1, 58 p.

Holburn, E.R., Fotherby, L.M., Randle, T.J., and Carlson, D.E., 2006, Trends of aggradation and degradation along the central Platte River, 1985 to 2005: Denver, Colo., Bureau of Reclamation, Technical Service Center, 180 p.

Joeckel, R.M., and Henebry, G.M., 2008, Channel and island change in the lower Platte River, eastern Nebraska, USA1855-2005: Geomorphology, v. 102, p. 407-418.

Johnson, W.C., 1994, Woodland expansions in the Platte River, Nebraska-Patterns and causes: Ecological Monographs, v. 64, p. 45-84.

Johnson, W.C., and Boettcher, S.E., 2000, The pre-settlement Platte-Wooded or prairie river?: Great Plains Research, v. 10, p. $39-68$.

Kinzel, P.J., Nelson, J.M., Parker, R.S., Bennett, J.P., and Topping, D.J., 1999, Grain-size evolution of the Platte River, 1931-1998, in Proceedings of the 10th Platte River Basin Ecosystem Symposium, February 23-24, 1999, Kearney, Nebraska, p. 9-14.

Kinzel, P.J., and Runge, J.T., 2010, Summary of bed-sediment measurements along the Platte River, Nebraska, 1931-2009: U.S. Geological Survey Fact Sheet 2010-3087, 4 p.

Kircher, J.E., 1981, Sediment analyses for selected sites on the South Platte River in Colorado and Nebraska-Suspended sediment, bedload, and bed material: U.S. Geological Survey Open-File Report 81-207, 48 p.

Lyons, J.K., and Randle, T.J., 1988, Platte River channel characteristics in the Big Bend reach: Denver, Colo., Bureau of Reclamation, 29 p.

Reid, L.M., and Dunne, Thomas, 1996, Rapid evaluation of sediment budgets: Reiskirchen, Germany, Catena Verlag GMBH, 164 p.

Sekely, A.C., Mulla, D.J., and Bauer, D.W., 2002, Streambank slumping and its contribution to the phosphorus and suspended sediment loads of the Blue Earth River, Minnesota: Journal of Soil and Water Conservation, v. 57, p. 243-250.

Simon, Andrew, and Darby, S.E., 1999, The nature and significance of incised river channels, in Incised river channelsProcesses, forms, engineering and management: New York, John Wiley and Sons, p. 3-18.

Smith, N.D., 1971, Transverse bars and braiding in the lower Platte River, Nebraska: Geological Society of America Bulletin, v. 82 , p. 3,407-3,420. 
Soenksen, P.J., Miller, L.D., Sharpe, J.B., and Watton, J.R., 1999, Peak-flow frequency relations and evaluation of the peak-flow gaging network in Nebraska: U.S. Geological Survey Water Resources Investigations Report 99-4032, $47 \mathrm{p}$.

U.S. Army Corps of Engineers, 1935, Letter from the Secretary of War ... General plan for the improvement of Missouri River, for the purposes of navigation and efficient development of its water power, the control of floods, and the needs of irrigation: U.S. Congress, 73d, Washington, D.C., 1935, session 2d, House Document 238, p. $1,032-1,245$.

U.S. Army Corps of Engineers, 2008, The Lower Platte River cumulative impact study phase 2 final report-Overview of the geographic information system (GIS), trend analysis, and hydrologic analysis: Omaha, Nebr., U.S. Army Corps of Engineers, $52 \mathrm{p}$.

Williams, G.P., 1978, The case of the shrinking channels-The North Platte and Platte Rivers in Nebraska: U.S. Geological Survey Circular 781, 48 p. 


\section{Appendix}


Water-Data Report 2010

412723096522801 Platte River below Murphy Isle, near North Bend, Nebr.

Lower Platte Basin

Lower Platte-Shell Subbasin

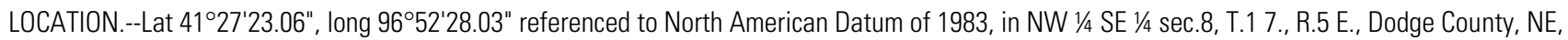
Hydrologic Unit 10200201.

\section{WATER-QUALITY RECORDS}

\section{WATER-QUALITY DATA \\ WATER YEAR OCTOBER 2009 TO SEPTEMBER 2010}

Part 1 of 2

[mm, millimeter; mm, millimeters]

\begin{tabular}{|c|c|c|c|c|c|c|c|}
\hline Date & $\begin{array}{c}\text { Sample } \\
\text { start } \\
\text { time }\end{array}$ & Medium name & $\begin{array}{c}\text { Sample } \\
\text { type }\end{array}$ & Sampler type & $\begin{array}{c}\text { Bed } \\
\text { sediment, } \\
\text { dry sieved, } \\
\text { sieve } \\
\text { diameter, } \\
\text { percent } \\
\text { smaller } \\
\text { than } 0.0625 \\
\text { mm }\end{array}$ & $\begin{array}{c}\text { Bed } \\
\text { sediment, } \\
\text { dry sieved, } \\
\text { sieve } \\
\text { diameter, } \\
\text { percent } \\
\text { smaller } \\
\text { than } 0.125 \\
\mathrm{~mm}\end{array}$ & $\begin{array}{c}\text { Bed } \\
\text { sediment, } \\
\text { dry sieved, } \\
\text { sieve } \\
\text { diameter, } \\
\text { percent } \\
\text { smaller } \\
\text { than } 0.25 \\
\text { mm }\end{array}$ \\
\hline 07-30-2010 & 1630 & Bottom material & Replicate & Sampler US BMH-53 & 1 & 1 & 29 \\
\hline $07-30-2010$ & 1631 & QC sample - Bottom material & Replicate & Sampler US BMH-53 & .0 & 1 & 24 \\
\hline $07-30-2010$ & 1632 & QC sample - Bottom material & Replicate & Sampler US BMH-53 & 1 & 1 & 28 \\
\hline $07-30-2010$ & 1633 & QC sample - Bottom material & Replicate & Sampler US BMH-60 & .0 & 1 & 22 \\
\hline $07-30-2010$ & 1634 & QC sample - Bottom material & Replicate & Sampler US BMH-60 & 1 & 1 & 25 \\
\hline $07-30-2010$ & 1635 & QC sample - Bottom material & Replicate & Sampler US BMH-60 & .0 & 1 & 23 \\
\hline
\end{tabular}

WATER-QUALITY DATA

WATER YEAR OCTOBER 2009 TO SEPTEMBER 2010

Part 2 of 2

[mm, millimeter; mm, millimeters]

\begin{tabular}{|c|c|c|c|c|}
\hline Date & $\begin{array}{c}\text { Bed } \\
\text { sediment, } \\
\text { dry sieved, } \\
\text { sieve } \\
\text { diameter, } \\
\text { percent } \\
\text { smaller } \\
\text { than } 0.5 \\
\text { mm }\end{array}$ & $\begin{array}{c}\text { Bed } \\
\text { sediment, } \\
\text { dry sieved, } \\
\text { sieve } \\
\text { diameter, } \\
\text { percent } \\
\text { smaller } \\
\text { than } 1 \mathrm{~mm}\end{array}$ & $\begin{array}{c}\text { Bed } \\
\text { sediment, } \\
\text { dry sieved, } \\
\text { sieve } \\
\text { diameter, } \\
\text { percent } \\
\text { smaller } \\
\text { than } 2 \mathrm{~mm}\end{array}$ & $\begin{array}{c}\text { Bed } \\
\text { sediment, } \\
\text { dry sieved, } \\
\text { sieve } \\
\text { diameter, } \\
\text { percent } \\
\text { smaller } \\
\text { than } 4 \mathrm{~mm}\end{array}$ \\
\hline 07-30-2010 & 78 & 92 & 98 & 100 \\
\hline $07-30-2010$ & 75 & 91 & 98 & 100 \\
\hline $07-30-2010$ & 79 & 93 & 98 & 100 \\
\hline $07-30-2010$ & 73 & 90 & 98 & 100 \\
\hline $07-30-2010$ & 79 & 94 & 99 & 100 \\
\hline $07-30-2010$ & 78 & 94 & 99 & 100 \\
\hline
\end{tabular}


Publishing support provided by:

Rolla Publishing Service Center

For more information concerning this publication, contact: Director, USGS Nebraska Water Science Center 5231 South 19 Street

Lincoln, NE 68512

(402) 328-4100

Or visit the Nebraska Water Science Center Web site at: http://ne.water.usgs.gov 


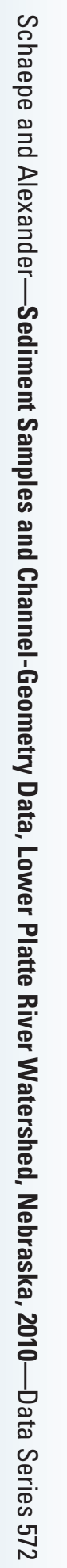

